\title{
Climate changes of hydrometeorological and hydrological extremes in the Paute basin, Ecuadorean Andes
}

\author{
D. E. Mora ${ }^{1,2}$, L. Campozano ${ }^{5,6}$, F. Cisneros ${ }^{2}$, G. Wyseure ${ }^{4}$, and P. Willems ${ }^{1,3}$ \\ ${ }^{1}$ KU Leuven, Hydraulics Divison, Kasteelpark Arenberg 40, 3001 Leuven, Belgium \\ ${ }^{2}$ Universidad de Cuenca, PROMAS, Av. 12 de abril, Cuenca, Ecuador \\ ${ }^{3}$ Vrije Universiteit Brussel, Department of Hydrology \& Hydraulic Engineering, Pleinlaan 2, 1050 Brussels, Belgium \\ ${ }^{4}$ Katholieke Universiteit Leuven, Soil and Water Management Divison, Celestijnenlaan 200E, 3001 Leuven, Belgium \\ ${ }^{5}$ Universidad de Cuenca, Dpto. RR HH y CC Ambientales, Av. 12 de abril, Cuenca, Ecuador \\ ${ }^{6}$ LCRS, Fac. of Geography, University of Marburg, Marburg, Germany
}

Correspondence to: D. E. Mora (diego.mora@ucuenca.edu.ec)

Received: 30 April 2013 - Published in Hydrol. Earth Syst. Sci. Discuss.: 24 May 2013

Revised: 12 December 2013 - Accepted: 6 January 2014 - Published: 19 February 2014

\begin{abstract}
Investigation was made on the climate change signal for hydrometeorological and hydrological variables along the Paute River basin, in the southern Ecuador Andes. An adjusted quantile perturbation approach was used for climate downscaling, and the impact of climate change on runoff was studied for two nested catchments within the basin. The analysis was done making use of long daily series of seven representative rainfall and temperature sites along the study area and considering climate change signals of global and regional climate models for IPCC SRES scenarios A1B, A2 and B1. The determination of runoff was carried out using a lumped conceptual rainfall-runoff model. The study found that the range of changes in temperature is homogeneous for almost the entire region with an average annual increase of approximately $+2.0^{\circ} \mathrm{C}$. However, the warmest periods of the year show lower changes than the colder periods. For rainfall, downscaled results project increases in the mean annual rainfall depth and the extreme daily rainfall intensities along the basin for all sites and all scenarios. Higher changes in extreme rainfall intensities are for the wetter region. These lead to changes in catchment runoff flows, with increasing high peak flows and decreasing low peak flows. The changes in high peak flows are related to the changes in rainfall extremes, whereas the decreases in the low peak flows are due to the increase in temperature and potential evapotranspiration together with the reduction in the number of wet days.
\end{abstract}

\section{Introduction}

The impact of climate change on hydrological systems is receiving higher attention during the last decades due to its consequences on water resources, especially related to droughts and floods (Nijssen et al., 2001; Hirabayashi et al., 2008; Urrutia and Vuille, 2009; Dirmeyer et al., 2012). Changes in rainfall are strongly related to changes in runoff and therefore with water availability (Bradly et al., 2006). Changes in temperature, humidity, and atmospheric pressure are related to changes in evapotranspiration, which is also an important input of the hydrological system. In addition, rainfall intensity is a primary weathering agent for rocks and soils increasing the transport of sediments and dissolved solids to water bodies. Furthermore, hydrological processes at the land surface influence the natural environment at a range of spatial and temporal scales through their impacts on biological activity and water chemistry (Beldring et al., 2008). This is also the case for the Paute River basin in Ecuador, where future climate change might severely impact hydrological and ecological conditions. Especially the water availability is a concern (Ontaneda et al., 2002), due to changes in temperature and humidity and high variability in rainfall extreme events (Parry et al., 2007).

A common methodology to quantify climate change signals makes use of general circulation model or global climate model (GCM) results. These results might, however, be too coarse to provide regional and local details, and should 
not be used directly for hydrological modeling, especially for regions with a high spatial and temporal variability in climate variables. This is the case of the Paute River basin in the tropical Andes in southern Ecuador (Célleri et al., 2007; Mora and Willems, 2012). One solution is the use of regional climate model (RCM) results, which provides finer-scale information. However, Buytaert et al. (2010) state that for some tropical regions and scales of aggregation, RCM simulations, especially for precipitation, do not necessarily give better results compared with GCM simulations. In addition, Cloke et al. (2013) conclude that the inability of some RCMs to produce realistic precipitation to be used in local climate impact studies for flooding, even in present conditions, is a serious issue. Two available RCM were considered in this study: the Precis Hadley and the Precis Echam (see Table 1).

To solve this problem, different statistical downscaling techniques, with different strengths and weaknesses (Fowler et al., 2007) were developed in order to obtain a higher spatial resolution (Giorgi et al., 2001; Hewitson and Crane, 1996). The application of these downscaling techniques to climate variables as rainfall and temperature may account for the mesoscale hydro-climatologic processes for areas of complex topography. In the study of Maraun et al. (2010), a perfect prognosis statistical downscaling, model output statistics and weather generators were reviewed as an improvement of the representation of rainfall space-time variability. The main uncertainties arise for the representation of extreme precipitation, subdaily precipitation and full precipitation fields on fine scales. Within the statistical downscaling techniques, the delta change or perturbation techniques are developed to translate large-scale GCM/RCM outputs onto a finer resolution based on change factors (Prudhomme et al., 2002; Willems et al., 2012). The change factors consider the differences between control and future GCM/RCM simulations and are applied to observed series.

Taking this state of the art into account, this paper aims to estimate future scenario projections for temperature, rainfall and discharge within the Paute River basin for 20452065. This is done with the application of an adjusted change factor-based statistical downscaling method, the quantile perturbation approach (QPA). The effect of changes in temperature and rainfall are used to estimate changes in discharge for two catchments in the basin. Following sections describe the study area, the data, the adjusted QPA and the evaluation of the approach. This is followed by a section that presents and discusses the climate change impact results. The final section summarizes this study with some concluding remarks.

\section{Methodology}

\subsection{Study area}

The basin of the Paute River is located in the inter-Andean depression separating the western and Cordillera Real in southern Ecuador (Coltorti and Ollier, 2000). With an area of $5066 \mathrm{~km}^{2}$ and elevation range from 1840 to $4680 \mathrm{~m}$ a.s.l., the basin has a vital hydropower plant complex at its downstream end. The upper part of the basin is located only $62 \mathrm{~km}$ from the Pacific coast line at its western point. The downstream part of the basin ends in a scattered region between the Andes and the Amazon (Fig. 1). For the discharge analysis, two subcatchments within the Paute River basin are analyzed. The catchment of Tomebamba in Monay (To Mo) is located in the western headwaters of the Paute River basin. It has an extension of $1265 \mathrm{~km}^{2}$ and an elevation range between 2500 and $4680 \mathrm{~m}$ a.s.l. The city of Cuenca is located within this catchment with nearly 350000 inhabitants (the third largest city). The catchments consist mainly of tropical alpine grasslands (páramo) and native forests, agriculture and urban areas. Within the catchment of To Mo, the subcatchment of Matadero in Sayausi (Ma Sa) is located, with an area of $300 \mathrm{~km}^{2}$ that covers mainly páramo and native forest land use.

\subsection{Database}

The Paute River basin is one of the most monitored basins in Ecuador. It has rainfall and temperature observation records since 1963 due to its importance in hydropower energy production. For this research, 7 sites located in different rainfall regime regions and at varying elevations were selected. The available data series start near 1962-1964 and continue till 1992-1993 with daily series for rainfall and monthly series for mean temperature. The names and characteristics of these sites are shown in Table 1. The available GCM-RCM control and scenario simulations covering Ecuador, which were considered in this study, are shown in Table 1. The control runs are available with daily simulation results for the historical period 1961-1990 and the future scenario simulation results for 2045-2065. The simulated future greenhouse gas emissions were based on the IPCC Special Report on Emission Scenario (SRES) for the A1B, A2 and B1 scenarios (Nakicenovic et al., 2000; Solomon et al., 2007).

\subsection{Perturbation or delta approach}

The perturbation approach is the most common method to transfer the signal of climate change from a climate system level represented by climate models to the hydrological system level represented by hydrological models (Middelkoop et al., 2001; Andréasson et al., 2004; Nguyen et al., 2007; Olsson et al., 2012; Willems et al., 2012). This method is applied to the most relevant climate variables in hydrology, notably rainfall, temperature and $\mathrm{ET}_{0}$. In its most simple form, monthly perturbation factors (PF), Eqs. (1) and (2), are determined and applied to the input series of hydrological models:

$$
\begin{aligned}
& T_{\mathrm{F}, \text { daily }}=T_{\mathrm{ob} \text {,daily }}+\left(T_{\mathrm{CMF}, \text { monthly }}-T_{\mathrm{CM} 20 \text { th,monthly }}\right) \\
& P_{\mathrm{F}, \text { daily }}=P_{\mathrm{ob} \text {,daily }} \cdot\left(\frac{P_{\mathrm{CMF} \text { monthly }}}{P_{\mathrm{CM} 20 \text { th,monthly }}}\right)
\end{aligned}
$$




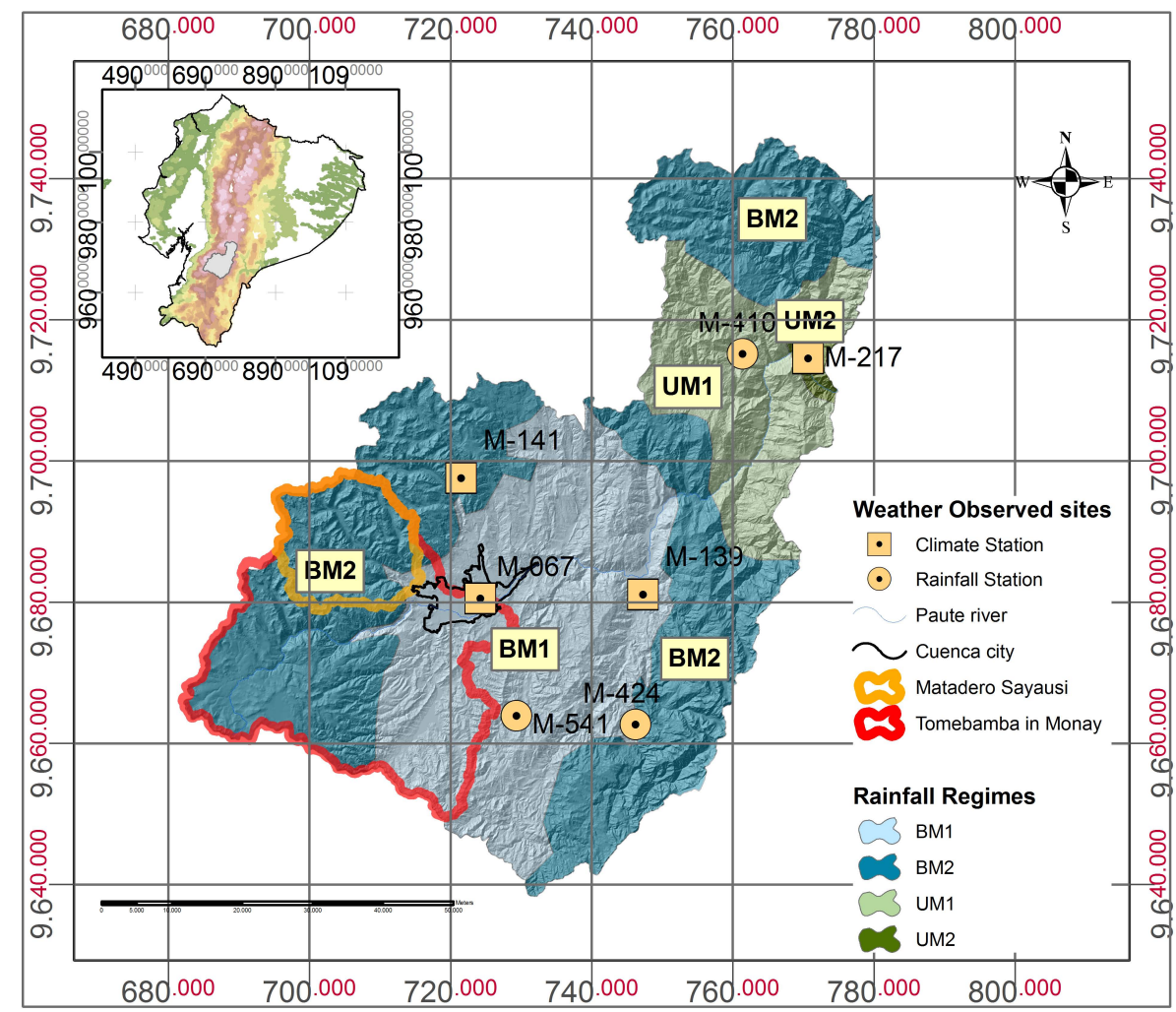

Fig. 1. Rainfall regimes in the Paute River basin (spatial regions BM1, BM2, UM1 and UM2).

where $T_{\mathrm{ob}}$ and $P_{\mathrm{ob}}$ are the observed temperature and rainfall values in the series, $T_{\mathrm{CM} 20 \text { th }}$ and $P_{\mathrm{CM} 20 \text { th }}$ the 20th century climate model control run results, $T_{\mathrm{CMF}}$ and $P_{\mathrm{CMF}}$ the projected future climate model results and $T_{\mathrm{F}}$ and $P_{\mathrm{F}}$ the projected future results after perturbation.

However, some of the disadvantages of this method include the assumption of no shift in the shape and type of changes. Extremes are indeed modified by the same factor as the other events. In addition, the assumption of no change in the number or the frequency of events is another disadvantage (Harrold and Jones, 2003).

The adjusted perturbation approach considers a climate change signal on both the number of wet or dry days and on the rainfall intensity. The change in the rainfall intensity is calculated in a quantile-based way, making use of a quantile mapping technique (Nguyen et al., 2008; Ntegeka and Willems, 2008; Willems and Vrac, 2011) hence with the PF depending on the exceedance probability. The method is applied with a relative PF or an absolute shift in the rainfall intensity, depending on whether relative or absolute changes are applied.

The change in wet day frequency is calculated as the ratio of the number of wet days for the scenario period (20452065) over the number of wet days for the control period (1961-1990) considering that a wet day is any day with rainfall depth above a certain daily rainfall intensity threshold (wd_th). The PF on the wet day frequency $\left(\mathrm{PF}_{\mathrm{wf}}\right)$ is $>1$ when the scenario series have more wet days than the control series and $\mathrm{PF}_{\mathrm{wf}}$ is $<1$ when dry days should be added (or wet days should be removed) from the observed series.

Once the $\mathrm{PF}_{\mathrm{wf}}$ is obtained, the $\mathrm{PF}$ on the wet day rainfall intensity $\left(\mathrm{PF}_{\mathrm{ri}}\right)$ is determined in a quantile-based way by comparing ranked daily extremes from the control period vs. the scenario period. Instead of using a unique PF for all events, the rainfall intensity PF is obtained dependent on the empirical exceedance probability of the intensity (see Fig. 2). However, the application of a relative intensity PF on observed values close to zero will produce signal changes near to zero even if the PF is high, or vice versa, small absolute changes between scenario and control values might lead to excessive PF when the control value is close to zero. Therefore the inclusion of an absolute change applied to rainfall intensities $\alpha$ under a threshold exceedance probability is considered in the adapted methodology. For high rainfall intensities corresponding to exceedance probabilities below $p(\alpha)$, a relative rainfall intensity PF is applied. For rainfall intensities corresponding to exceedance probabilities above $p(\alpha)$ the rainfall intensity change is derived by calculation of a weighted average of the relative and absolute rainfall intensity changes. The weighting factor varies linearly between $p(\alpha)$ and $p(0)$, where $p(0)$ is the exceedance probability of the ranked rainfall intensities equal to the wet day threshold 
Table 1. GCM/RCM runs for the Ecuadorean region (top), and observed rainfall/temperature sites (bottom).

\begin{tabular}{|c|c|c|c|}
\hline Model run & Center & Country & \\
\hline 1. cccr_bcm2_0 & Bjerknes Centre for Climate Research & Norway & \\
\hline $\begin{array}{l}\text { 2. cccma_cgcm3_1 } \\
\text { 3. cccma_cgcm3_1_t63 } \\
\text { 4. crm_cm 3 }\end{array}$ & $\begin{array}{l}\text { Canadian Centre for Climate Modelling } \\
\text { and Analysis }\end{array}$ & Canada & \\
\hline $\begin{array}{l}\text { 5. csiro_mk3_0 } \\
\text { 6. csiro_mk3_5 }\end{array}$ & $\begin{array}{l}\text { Australia's Commonwealth Scientific and } \\
\text { Industrial Research Organization }\end{array}$ & Australia & \\
\hline $\begin{array}{l}\text { 7. gfdl_cm2_0 } \\
\text { 8. gfdl_cm2_1 }\end{array}$ & Geophysical Fluid Dynamics Laboratory & USA & \\
\hline $\begin{array}{l}\text { 9. giss_aom } \\
\text { 10. giss_model_e_r }\end{array}$ & Goddard Institute for Space Studies & USA & \\
\hline 11. iap_fgoals1_0_g & Institute of Atmospheric Physics & China & \\
\hline 12. ingv_echam4 & National Institute of Geophysics and Volcanology & Italy & \\
\hline 13. inmcm3_0 & Institute for Numerical Mathematics & Russia & \\
\hline 14. ipsl_cm4 & Institute Pierre Simon Laplace & France & \\
\hline $\begin{array}{l}\text { 15. miroc3_2_hires } \\
\text { 16. miroc3_2_medres }\end{array}$ & Meteorological Research Institute, Japan & Japan & \\
\hline 17. miub_echo_g & Meteorological Institute, University of Bonn & Germany & \\
\hline 18. mpi_echam5 & Max-Planck Institute for Meteorology & Germany & \\
\hline 19. mri_cgcm2_3_2a & National Institute for Environmental Studies & Japan & \\
\hline $\begin{array}{l}\text { 20. ncar_ccsm3_0 } \\
\text { 21. ncar_pcm } 1\end{array}$ & National Centre for Atmospheric Research & USA & \\
\hline 22. Precis Hadley & Hadley Center & UK & \\
\hline 23. Precis Echam & Hadley Center/Max-Planck Institute for Meteorology & UK/Germany & \\
\hline Site & Name & Elevation & Region \\
\hline M410 & Rio Mazar-Rivera & 2600 & UM1 \\
\hline M217 & Penas Coloradas & 2000 & UM2 \\
\hline M139 & Gualaceo & 2360 & BM1 \\
\hline M067 & Cuenca Aeropuerto & 2516 & BM1 \\
\hline M424 & Sigsig INAMHI & 2600 & BM2 \\
\hline M141 & El Labrado & 3260 & BM2 \\
\hline M541 & Cochapamba-Quingeo & 2760 & BM1 \\
\hline
\end{tabular}

on the observed series (see Fig. 3). In case $\mathrm{PF}_{\mathrm{wf}}>1$, wet days need to be added to the observed series to obtain perturbed series. The intensities of these days are taken from the absolute change in rainfall intensity corresponding to exceedance probabilities above $p(0)$. For the addition of the different wet/dry days, the wet/dry spells are first identified in the observed series and ranked per month according to rainfall volume and duration of the different spells. In the case new days need to be added, the first wet day will be added at the end of the highest/longer rainfall volume/duration wet spell. A second day will be added at the end of the second highest/longer spell and so on. In case that a dry day is added, a wet day rainfall intensity will be changed to zero at the end of the lowest/shorter rainfall spell. In case the number of new wet or dry days is higher than the number of wet or dry spells, the addition of new days will start again in the ranked spells.
This method solves the above mentioned problem related to the application of a relative PF to low rainfall intensities and allows to determine the rainfall intensity values of the additional wet days.

\subsection{Rainfall-runoff model}

The downscaled future series of rainfall and evapotranspiration were used for the study of the climate change impact on river discharges based on a calibrated lumped conceptual model with emphasis on the peak flows. The model has been implemented using the generalized lumped conceptual and parsimonious model-structure identification and calibration (VHM) approach of Willems $(2000,2014)$ and Willems et al. (2014). The model was previously calibrated and validated for the To Mo and Ma Sa catchments (Célleri 

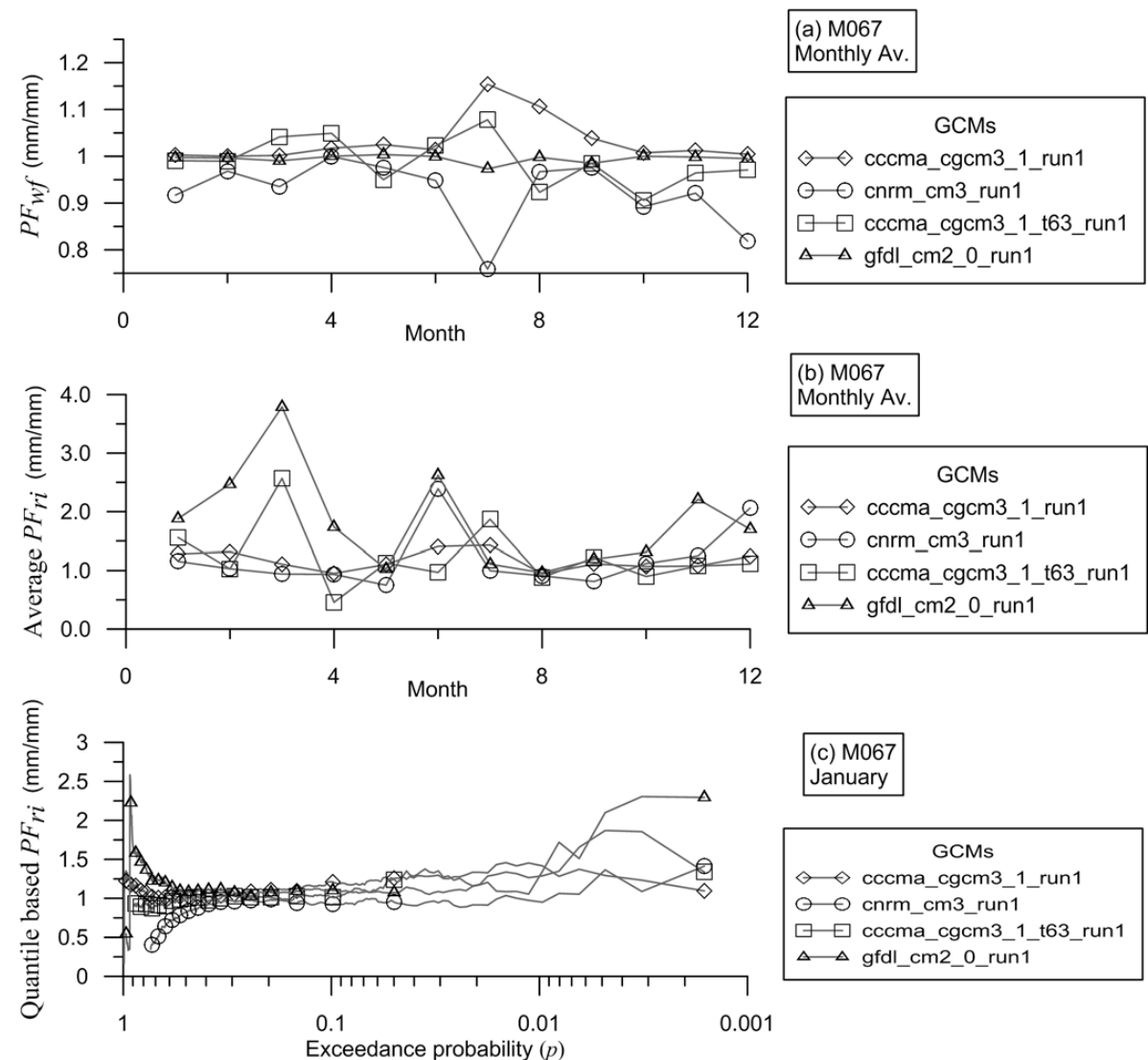

(c) M067

January

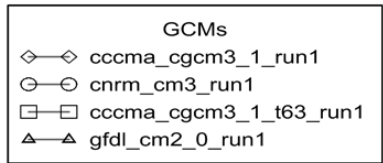

$\exists \square$ cccma_cgcm3_1_t63_run1

$\Delta \Delta$ gfdl_cm2_0_run1

Fig. 2. (a) Perturbation factor of the wet day frequency $\mathrm{PF}_{\mathrm{wf}}$, (b) perturbation factor of the rainfall intensity $P F_{\mathrm{ri}}$ averaged for each month and (c) quantile-based $\mathrm{PF}_{\mathrm{ri}}$ for January in site M067 for the four selected GCM runs.

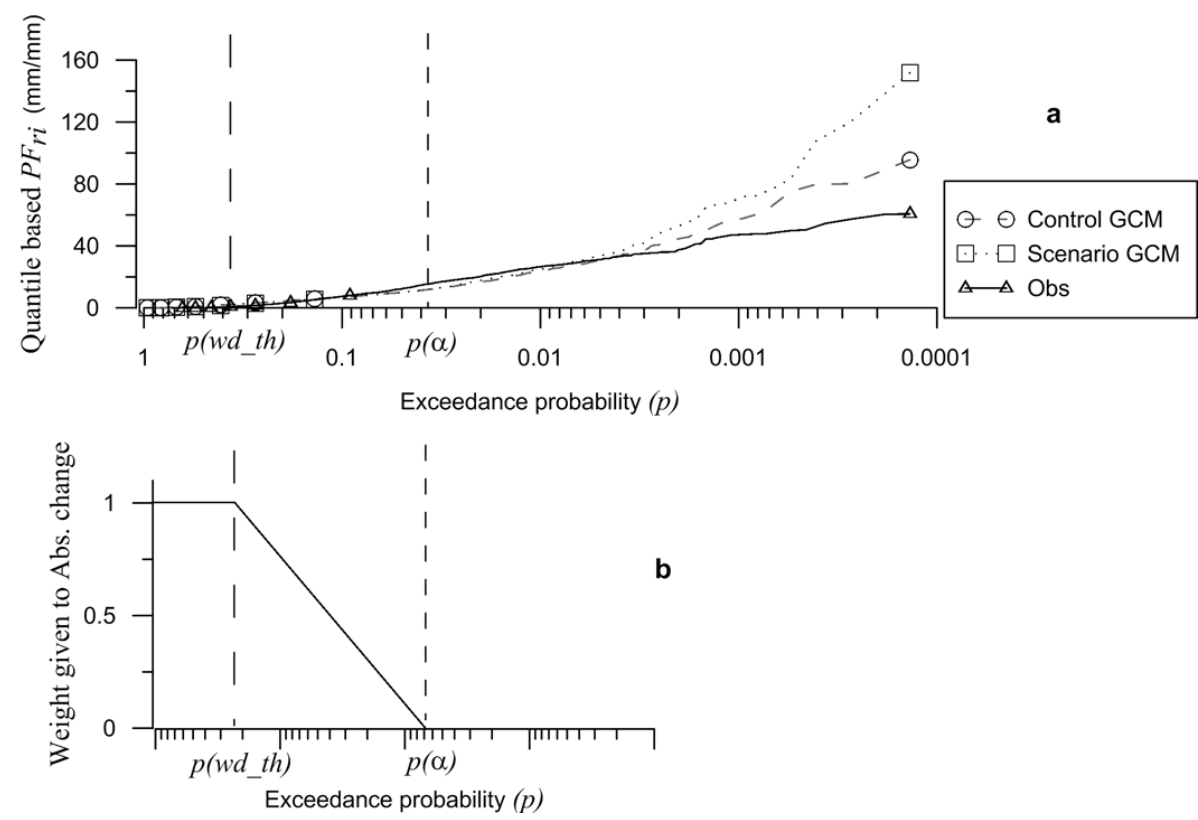

Fig. 3. (a) Illustration of the second adjustment to the QPA including an exceedance probability threshold value $p(\alpha)$ for site M067 and GCM run cnrm_cm3_run1; (b) relative weight given to absolute change (vs. relative change). 
et al., 2010), and previously applied for hydrological climate change or variability impact analysis by Taye et al. (2011), Liu et al. (2011), Van Steenbergen and Willems (2012) and Taye and Willems (2013).

The equations of Penman-Monteith (Penman, 1948; Monteith, 1965) were used to estimate future evapotranspiration $\left(\mathrm{ET}_{0}\right)$ series considering the future temperature series previously described. For the calculation of $\mathrm{ET}_{0}$, future series of maximum, mean and minimum air temperature were applied. Future catchment rainfall and $\mathrm{ET}_{0}$ were estimated with the downscaled climate model output series at each site and lumped at catchment scale by interpolation using the inverse distance squared method. However, attention must be paid to the moment of using the estimated future $\mathrm{ET}_{0}$ series. The Penman-Monteith equation involves other parameters than temperature, which were not taken into account in this research and therefore were kept constant. Future series of solar radiation, humidity and wind speed, among others, may have an influence on the future $\mathrm{ET}_{0}$ as well. According to Vuille et al. (2003), humidity and convective cloud cover tend to increase in the region. This might have an impact on the future $\mathrm{ET}_{0}$, increasing discharge peaks and reducing the frequency of low flows.

\subsection{Impact indicators}

In order to evaluate the impact of the different climate scenario projections on temperature, rainfall and runoff, few statistics are used as impact indicators. These indicators summarize the changes between historical and future conditions. To evidence the influence of the downscaling technique, the indicators are first calculated based on the GCM-RCM results, considering changes between the future and the control period series. Subsequently, the high climate variability along the study area, for both temperature and rainfall, are described in function of these indicators. Finally, the impact indicators based on the GCM-RCM outputs are compared against the impact indicators derived from the downscaled series. This comparison is for the future projections based on the SRES scenario A2, as results from one RCM is also available for this scenario. Based on the analysis of the indicators, the influence of the local site specific properties, the statistical downscaling technique and the interaction with the changes projected by the climate model simulations is studied.

The impact indicators considered in this study focus on the change in annual and monthly mean values, in the frequency of wet-dry days, and in annual and daily values at different quantiles. The change in the frequency accounts the change in the number of wet days. A wet day is any daily rainfall depth higher than or equal to $0.5 \mathrm{~mm}$. The changes at different quantiles allow identifying the dependency of the changes with the probability of no exceedance (p.n.e.). For rainfall, quantiles are considered for 100, 99, 97, 95 and 90 p.n.e. This allows the changes to be analyzed for extremes.
For temperature, the quantiles are considered for 100, 75, 50, 25 and 0 p.n.e. also called quartiles (Max, $Q_{3}, Q_{2}, Q_{1}$, Min).

These impact indicators are calculated at each site for the ensemble of all GCM-RCM control and scenario run combinations and for the three future scenarios A1B, A2 and B1. Figure 4 shows, as an example, the impact indicators for rainfall change for scenario A2 at site M067. In the results and discussion section, results of the ensemble models are averaged.

\section{Results and discussion}

This section reports on the change in the downscaled series for temperature and rainfall at the seven sites previously described, and the change in runoff for the To Mo and $\mathrm{Ma} \mathrm{Sa}$ catchments.

\subsection{Spatio-temporal patterns from the observed series}

The observed series of rainfall and temperature show the presence of high spatial and temporal variability within the region for both variables. Table 2 shows some properties of temperature and rainfall at the observed sites. The spatial variability in temperature is explained by its correlation to elevation. Sites at higher elevations present lower temperatures than sites at lower elevations. The temperature gradient is ca. $-0.6{ }^{\circ} \mathrm{C}$ per $100 \mathrm{~m}$ increase in elevation. Figure 5 shows the spatio-temporal patterns in monthly averages within the Paute River basin based on the sites. There is a small temporal variability in temperature throughout the year. Warmer months are found during DJF and colder months during JJA. The seasonal distribution of temperature is similar at all sites, but with different magnitudes. The same is valid for the distribution of quantiles.

To explain the variability in rainfall, Célleri et al. (2007) and Mora et al. (2012) classified the basin in four rainfall regime regions according to the annual rainfall distribution (see Fig. 1). Two rainfall regimes show a bimodal rainfall distribution, $\mathrm{BM} 1$ and $\mathrm{BM} 2$. BM1 is highly marked with two wet seasons during May-March-April (MMA) and September-October-November (SON), and two dry seasons during June-July-August (JJA) and December-JanuaryFebruary (DJF) and with annual rainfall depths between 700 and $900 \mathrm{~mm}$ (Fig. 5). Region BM2 presents a less notable bimodal annual distribution, but in similar to BM1. The annual rainfall depth for the BM2 region is about $1000 \mathrm{~mm}$. This region corresponds to the upstream part of the Paute basin, having páramo soils. The bimodal annual cycle is determined by the displacement of the intertropical convergence zone (ITCZ). In addition, rainfall regimes BM1 and BM2 are influenced by Pacific Ocean airstreams and the anticyclone from the south. The first one is a west-east direction current with two main rainy periods during February and March and other less intense rainy periods in October and 

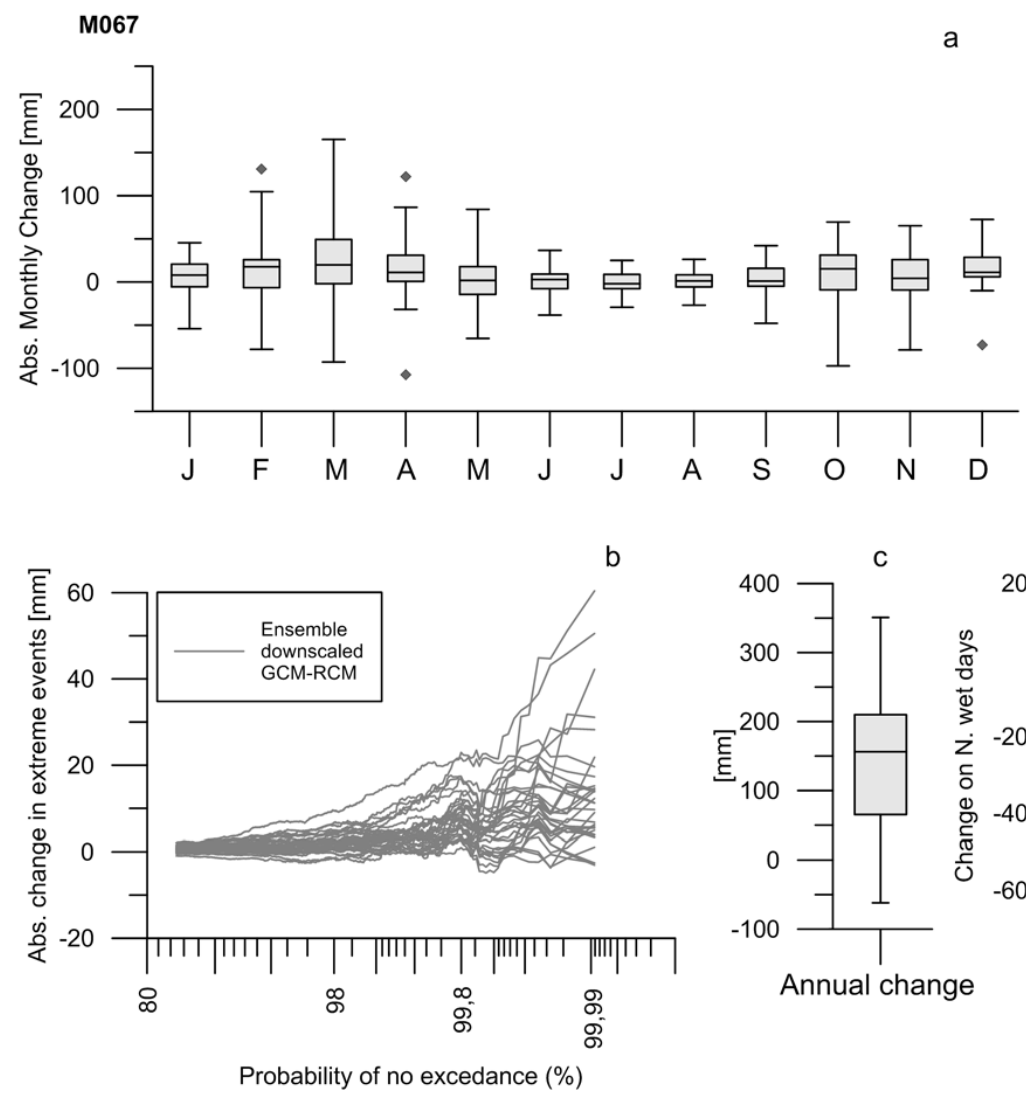

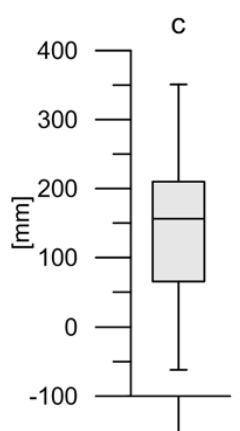

Annual change

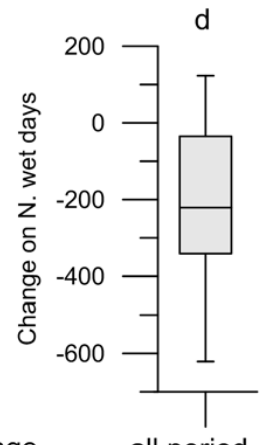

all period

Probability of no excedance $(\%)$

Fig. 4. Example of the impact indicators for downscaled rainfall change in site M065 (scenario A2). (a) Change of monthly rainfall depths, (b) change of rainfall depths at extreme quantiles, (c) change of annual rainfall depths and (d) change in the number of wet days.
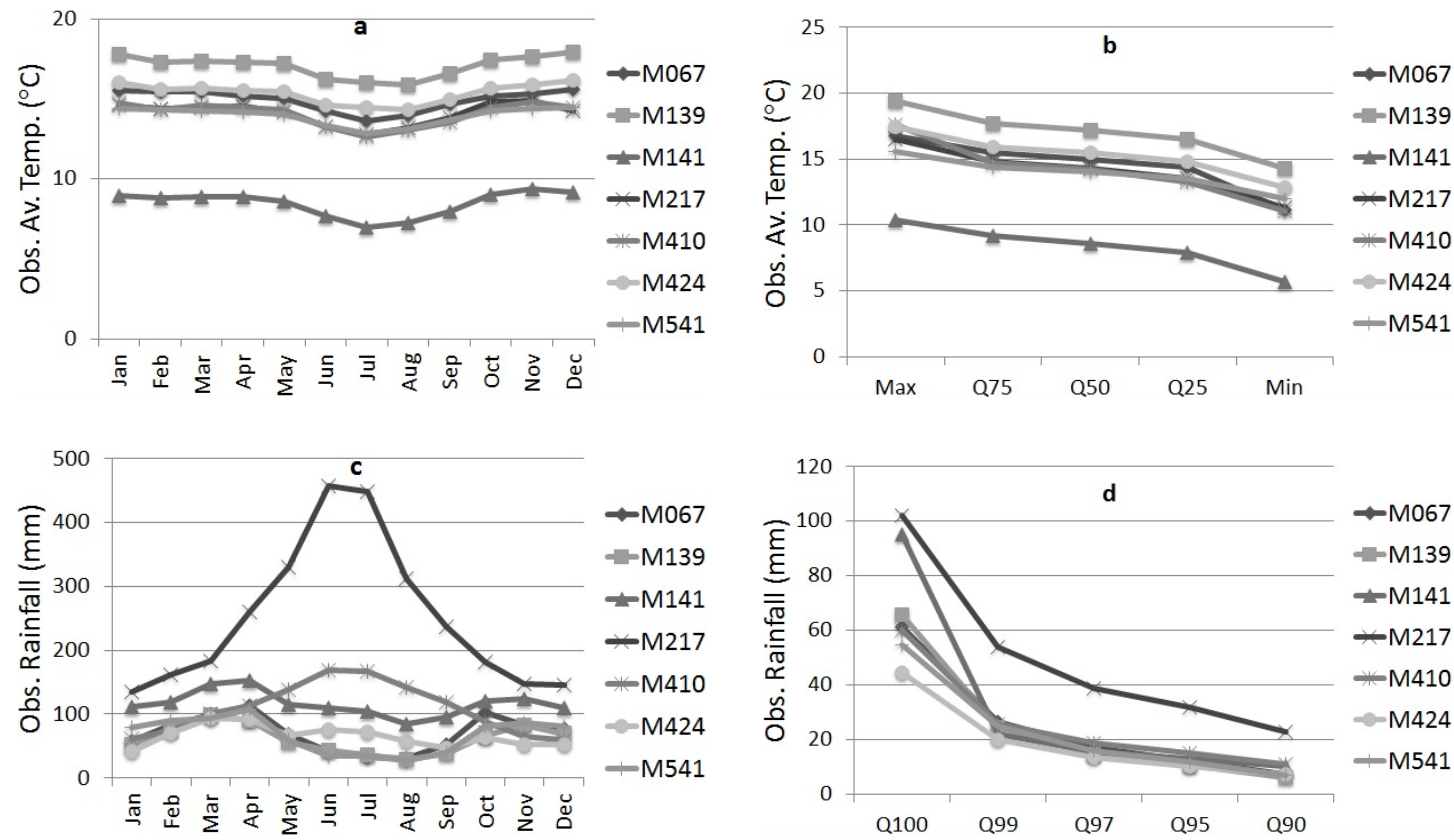

Fig. 5. Temperature and rainfall properties at observed sites (1960-1990). (a) Monthly average temperature distribution, (b) monthly temperature for different quantiles, (c) monthly rainfall depth distribution, (d) daily rainfall depths for different quantiles. 
Table 2. Observed mean annual temperature and rainfall, quantiles of monthly temperature, quantiles of daily rainfall depths, and number of wet/dry days at the observed sites during the control period (1960-1990).

\begin{tabular}{|c|c|c|c|c|c|c|c|c|c|}
\hline \multicolumn{2}{|c|}{ Temperature $\left({ }^{\circ} \mathrm{C}\right)$} & \multicolumn{8}{|c|}{ Quantiles } \\
\hline Site & Year & $\operatorname{Max}$ & $Q_{3}$ & $Q_{2}$ & $Q_{1}$ & Min & & & \\
\hline M067 & 14.9 & 16.8 & 15.5 & 15.0 & 14.4 & 11.1 & & & \\
\hline M139 & 17.1 & 19.4 & 17.7 & 17.2 & 16.5 & 14.3 & & & \\
\hline M141 & 8.4 & 10.4 & 9.2 & 8.6 & 7.9 & 5.7 & & & \\
\hline M217 & 14.1 & 16.5 & 14.8 & 14.3 & 13.5 & 11.3 & & & \\
\hline M410 & 14.0 & 17.6 & 14.7 & 14.2 & 13.3 & 11.1 & & & \\
\hline M424 & 15.3 & 17.5 & 15.9 & 15.5 & 14.8 & 12.9 & & & \\
\hline M541 & 13.9 & 15.6 & 14.4 & 14.0 & 13.5 & 12.0 & & & \\
\hline \multicolumn{2}{|c|}{ Rainfall (mm) } & \multicolumn{3}{|c|}{ Frequency } & \multicolumn{5}{|c|}{ Quantiles } \\
\hline Site & Year & $\begin{array}{l}N_{\text {wet }} \\
\text { days }\end{array}$ & $\begin{array}{l}N_{\text {dry }} \\
\text { days }\end{array}$ & $\begin{array}{c}\text { Ratio } \\
N_{\text {wet }} / N_{\text {total }}\end{array}$ & $Q_{100}$ & $Q_{99}$ & $Q_{97}$ & $Q_{95}$ & $Q_{90}$ \\
\hline M067 & 840 & 2800 & 4505 & 0.4 & 61.1 & 26.5 & 17.2 & 12.2 & 7.4 \\
\hline M139 & 736 & 2693 & 4612 & 0.4 & 65.7 & 24.2 & 14.5 & 10.7 & 6.2 \\
\hline M141 & 1392 & 6296 & 1009 & 0.9 & 95.3 & 22.0 & 15.6 & 13.2 & 10.0 \\
\hline M217 & 2997 & 5823 & 1482 & 0.8 & 101.9 & 53.9 & 38.8 & 31.8 & 22.6 \\
\hline M410 & 1296 & 4161 & 3144 & 0.6 & 60.0 & 25.6 & 18.8 & 15.1 & 10.8 \\
\hline M424 & 784 & 2951 & 4354 & 0.4 & 44.5 & 20.0 & 13.4 & 10.2 & 7.1 \\
\hline M541 & 813 & 2969 & 4336 & 0.4 & 54.6 & 24.7 & 15.7 & 11.9 & 6.8 \\
\hline
\end{tabular}

November. The El Niño phenomena have a major impact on this current. The anticyclone from the south is present during the south winter (JJA) and prevents precipitation in the southern part of the basin. The more uniform annual rainfall distribution for region BM2 is influenced by raising of coastal moisture along western Andes slopes.

Regions UM1 and UM2 are located in the downstream eastern part of the basin (Fig. 1). These regions are close to the tropical forest influence and to the easterly continental low level jet during austral winter (JJA), (Garreaud, 2009). This results in high annual rainfall depths of ca. $1300 \mathrm{~mm}$ for UM1 and $3000 \mathrm{~mm}$ for UM2. The annual distribution shows a single wetter season during JJA.

Table 1 shows that the ratio of the number of wet days over the total number of days is 0.4 for sites located at BM1 (M067, M139), 0.6 for sites at UM1 (M410), 0.8 for sites at UM2 (M217) and 0.85 for BM2 (site M141). This means that region $\mathrm{BM} 2$ has the highest number of wet days in the basin, even more wet days than regions UM1 and UM2 that are influenced by the tropical forest. As annual and monthly magnitudes vary from site to site, variability is also high for extreme events. High rainfall intensities (quantile $Q_{100}$ ) of about $100 \mathrm{~mm} \mathrm{day}^{-1}$ are found in site M217 (UM2). For sites located in regions $\mathrm{BM} 1$ and $\mathrm{BM} 2, Q_{100}$ quantile have daily intensities up to about $60 \mathrm{~mm} \mathrm{day}^{-1}$. The rainfall distribution shows that high intensities occur at $Q_{100}$ and $Q_{99}$. For all sites the rainfall intensity at $Q_{100}$ is about two times than at $Q_{99}$, and reduces strongly towards $Q_{95}$. Sites M141 and M217 have the highest extreme intensities. Regions
UM1 and UM2 are influenced by the Amazon airstream, which is a current that enters the basin from the east-west and is related to periods of higher rainfall between March and October.

\subsection{Impact indicators from the GCM-RCM series}

The different impact indicators were first calculated for the changes resulting directly from the climate model simulations, hence without the influence of statistical downscaling.

Table 3 shows that all sites in the basin have a similar change in mean annual temperature. This change is approximately $+2.0^{\circ} \mathrm{C}$ on average for all GCM simulations. Results from individual GCM simulations may, however, differ from that average; they range between +1.1 and $+2.9^{\circ} \mathrm{C}$. However, note that the change is the same for sites M067 and M541 and for M141 and M410 because they share the same pixel for most of the GCMs. The different GCM simulations also report similar annual average temperatures for all sites $\left(23^{\circ} \mathrm{C}\right)$. This is opposed to the spatial temperature variations we reported in Sect. 3.1. Due to the coarse resolution of the GCMs, the spatial variability because induced by the topographical variations is indeed not accounted for. This is different for the RCMs, where different pixels cover the spatial variability hence is better described by these regional models. However, when the simulation results are evaluated for the RCM Precis_echam model (not shown), the projected changes are approximately the same $\left(+2.6^{\circ} \mathrm{C}\right)$ for all sites. This change is about the same as for the Echam GCM $\left(+2.5^{\circ} \mathrm{C}\right)$. It shows that the changes (not the absolute 
Table 3. Impact indicators for temperature and rainfall output series of GCM-RCMs without downscaling for 2045-2065, scenario A2.

\begin{tabular}{|c|c|c|c|c|c|c|c|c|c|c|}
\hline \multirow{2}{*}{$\begin{array}{l}\text { Temperature } \\
\text { Site }\end{array}$} & \multirow{2}{*}{$\begin{array}{l}\text { Annual } \\
\text { mean } \\
{\left[{ }^{\circ} \mathrm{C}\right]}\end{array}$} & \multirow{2}{*}{$\begin{array}{c}\text { Abs. change } \\
\text { on annual } \\
\text { mean } \\
{\left[{ }^{\circ} \mathrm{C}\right]}\end{array}$} & \multicolumn{8}{|c|}{ Abs. changes quantiles $\left[{ }^{\circ} \mathrm{C}\right]$} \\
\hline & & & Max & & $Q_{3}$ & & $Q_{2}$ & & $Q_{1}$ & Min \\
\hline M067 & 22.5 & 2.0 & 2.0 & & 2.0 & & 2.0 & & 2.0 & 1.6 \\
\hline M139 & 22.4 & 2.1 & 2.2 & & 2.1 & & 2.1 & & 2.1 & 1.8 \\
\hline M141 & 22.6 & 2.0 & 2.3 & & 2.0 & & 2.0 & & 2.0 & 1.7 \\
\hline M217 & 22.6 & 2.0 & 2.3 & & 2.0 & & 2.0 & & 2.0 & 1.7 \\
\hline M410 & 22.5 & 2.0 & 2.3 & & 2.0 & & 2.0 & & 2.0 & 1.7 \\
\hline M424 & 22.5 & 1.9 & 2.0 & & 2.0 & & 2.0 & & 2.0 & 1.5 \\
\hline M541 & 22.5 & 2.0 & 2.0 & & 2.0 & & 2.0 & & 2.0 & 1.6 \\
\hline Rainfall & Annual & Abs. (Relative) & \multicolumn{3}{|c|}{ Frequency } & \multicolumn{5}{|c|}{ Abs. change in quantiles [mm] } \\
\hline Site & $\begin{array}{l}\text { mean } \\
{[\mathrm{mm}]}\end{array}$ & $\begin{array}{c}\text { change in } \\
\text { annual mean } \\
\text { [mm] ([\%]) } \\
\text { days }\end{array}$ & $\begin{array}{l}N_{\text {wet }} \\
\text { days }\end{array}$ & $\begin{array}{c}N_{\text {dry }} \\
N_{\text {wet }} / N_{\text {total }}\end{array}$ & Ratio & $Q_{100}$ & $Q_{99}$ & $Q_{97}$ & $Q_{95}$ & $Q_{90}$ \\
\hline M067 & 2030 & $104(5.4)$ & 5210 & 2095 & 0.7 & 11.0 & 2.6 & 1.5 & 1.0 & 0.8 \\
\hline M139 & 2030 & $104(5.4)$ & 5232 & 2073 & 0.7 & 11.0 & 2.6 & 1.5 & 1.0 & 0.8 \\
\hline M141 & 2135 & $104(5.0)$ & 5649 & 1656 & 0.8 & 9.9 & 2.6 & 1.4 & 0.9 & 0.6 \\
\hline M217 & 2135 & $101(5.0)$ & 5649 & 1656 & 0.8 & 9.9 & 2.6 & 1.4 & 0.9 & 0.6 \\
\hline M410 & 2135 & $101(5.0)$ & 5650 & 1655 & 0.8 & 9.9 & 2.6 & 1.4 & 0.9 & 0.6 \\
\hline M424 & 2030 & $102(5.4)$ & 5232 & 2073 & 0.7 & 11.0 & 2.6 & 1.5 & 1.0 & 0.8 \\
\hline M541 & 2030 & $104(5.4)$ & 5232 & 2073 & 0.7 & 11.0 & 2.6 & 1.5 & 1.0 & 0.8 \\
\hline
\end{tabular}

values) are primarily controlled by the GCM in which the $\mathrm{RCM}$ is nested. A similar conclusion was formulated by Wood et al. (2004), ho stated that a dynamical downscaling step does not lead to large improvement in retrospective hydrological simulation relative to the direct use of the GCM output. However, climate dynamics are intrinsically more detailed in RCMs and we believe that the use of RCM outputs should be considered in further research.

Temporal analysis of the monthly temperature (Fig. 6) shows higher changes in the monthly temperatures for the colder months June-July-August (JJA) (on average $+2.3{ }^{\circ} \mathrm{C}$ ) and lower changes for the warmer months DecemberJanuary-February (DJF) (on average $+1.9^{\circ} \mathrm{C}$ ). The changes for different quantiles show that most GCMs predict higher changes at higher temperatures. For the highest temperature monthly quantiles the changes are about $+2{ }^{\circ} \mathrm{C}$, whereas for the lowest monthly quantiles the temperature changes are about $+1.6{ }^{\circ} \mathrm{C}$ in all sites. The temporal distribution of temperature is similar for all sites, not only for the temporal changes but also for the absolutes temperature magnitudes. This again differs from the observed series, where higher spatial differences are noted (see Sect. 3.1).

Results for rainfall change (Table 3 and Fig. 6) are similar to those for temperature. The high rainfall variability is not described by the GCMs. The control and scenario series give similar annual rainfall depths for all sites. These result in a homogeneous annual rainfall change of about $102 \mathrm{~mm}$ on average for all GCM simulations. The annual rainfall change for individual GCM simulations ranges between -203 and $327 \mathrm{~mm}$. In contrast to the case of temperature, annual rainfall depth changes projected by the RCM Precis_echam differ much from site to site (not shown). This is different from the spatially homogenous changes in the results of the Echam GCM, in which the RCM is nested, about $(+72 \mathrm{~mm})$ for all sites. However, it is seen that the annual rainfall depths projected by the RCM during the control period differ strongly from the observed depths. The RCM projects increases in annual rainfall depths between +175 and $+650 \mathrm{~mm}$ for sites located in the BM1 and BM2 rainfall regions and $+1285 \mathrm{~mm}$ for region UM1. However, for site M410 located in region UM2, the model predicts a change of $-1450 \mathrm{~mm}$. More details about the performance of GCMs compared with observed series for this study area can be found in Mora et al. (2012).

The change in monthly rainfall depths is similar for all sites. The GCMs project nearly no change (ca. $+5 \mathrm{~mm}$ ) during JJA and negative changes (ca. $-45 \mathrm{~mm}$ ) for SON at all sites. The change in the frequency of events shows for all sites an increase in the number of wet days. This increase is similar for all sites. The ratio of the number of wet days over the total number of days is about 0.7. The RCM presents different ratios depending on the site, although these values again differ from the observed ones. Sites located in the eastern region (M424, M410, M217, M139) are projected 

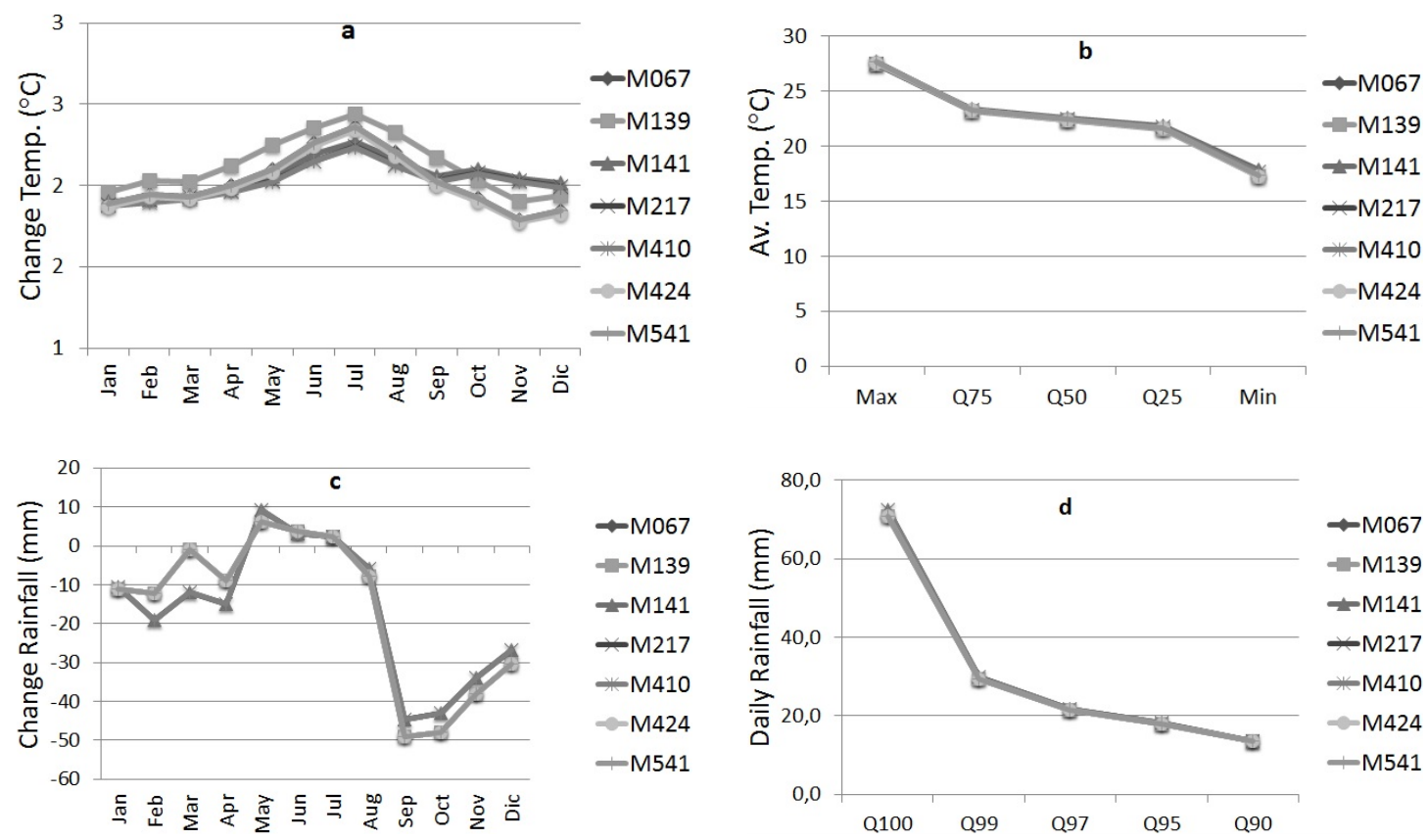

Fig. 6. Temperature and rainfall properties obtained from the average of ensemble GCM-RCM simulations (2045-2065). (a) Monthly average temperature distribution, (b) monthly temperature for different quantiles, (c) monthly rainfall depth distribution, (d) daily rainfall depth for different quantiles.

with a higher increase in the number of wet days (ratio $\approx 0.9$ ), independent of the rainfall regime region. In contrast, sites located in the western part of the basin (M067, M141, M541) have a lower increase in the number of wet days (ratio $\approx 0.55$ ). Changes in extreme daily rainfall quantiles are spatially homogeneous for most GCM simulations with relatively low changes (about $+10 \mathrm{~mm} \mathrm{day}^{-1}$ ). No significant changes are projected at the $99 \%$ quantile (about $+2.5 \mathrm{~mm} \mathrm{day}^{-1}$ ). The spatial pattern of changes in quantiles again differs from the pattern of the observed quantiles. There is no need to have both patterns the same, because changes are controlled by large-scale circulation whereas absolute rainfall values are more affected by local (topographical) conditions. However, also the absolute rainfall results differ much from the observed values, and some changes are inconsistent with the observations. The RCM-based change in annual rainfall depth of $-1450 \mathrm{~mm}$ at site M410 is for instance higher than the observed annual rainfall depth of $1300 \mathrm{~mm}$ at that site. That climate models are less reliable in the simulation of precipitation than temperature has been reported by many researchers (Parry et al., 2007; Buytaert et al., 2010). This does, however, not mean that the climate model results for precipitation cannot be trusted. The change signal from both, GCM and RCM simulations, are mainly greenhouse gas scenario driven. Transferring this signal to the local-scale changes is one of the aims of statistical downscaling. Converting the coarse spatial-scale precipitation from GCM-RCMs to the local scale by making use of local observations is proposed with the present downscaling technique. These local observations are expected to intrinsically reflect the effect of local, mainly topography driven, small-scale conditions.

\subsection{Impact indicators from the downscaled series}

The same impact indicators but applied to the downscaled observed versus the observed series are shown in Tables 4 and 5 and Fig. 7.

Similar to the changes obtained directly from the climate models, the changes in downscaled mean annual temperature show a spatially uniform value of about $+2.0^{\circ} \mathrm{C}$ on average for all sites. The individual GCM simulations give changes that range between +0.4 and $+2.9{ }^{\circ} \mathrm{C}$. Also based on the RCM model results, no strong spatial variation in these changes is found. Moreover, the temporal variations in mean monthly temperature changes after statistical downscaling are similar to those obtained from the climate model outputs. They show higher changes of about $+2.3^{\circ} \mathrm{C}$ during colder months (JJA), and lower changes of about $+1.9^{\circ} \mathrm{C}$ for DJF. The monthly temperature quantile distribution, however, differs from site to site. This is in contrast to the temperature quantile distributions projected by the climate models. In addition, the monthly quantile distributions of downscaled temperature are close to those derived from the observed series, whereas the climate model outputs show a less uniform temperature distribution. It is expected that this is due to the influence of the topographical variations on the local temperature dynamics. Because this influence is reflected 

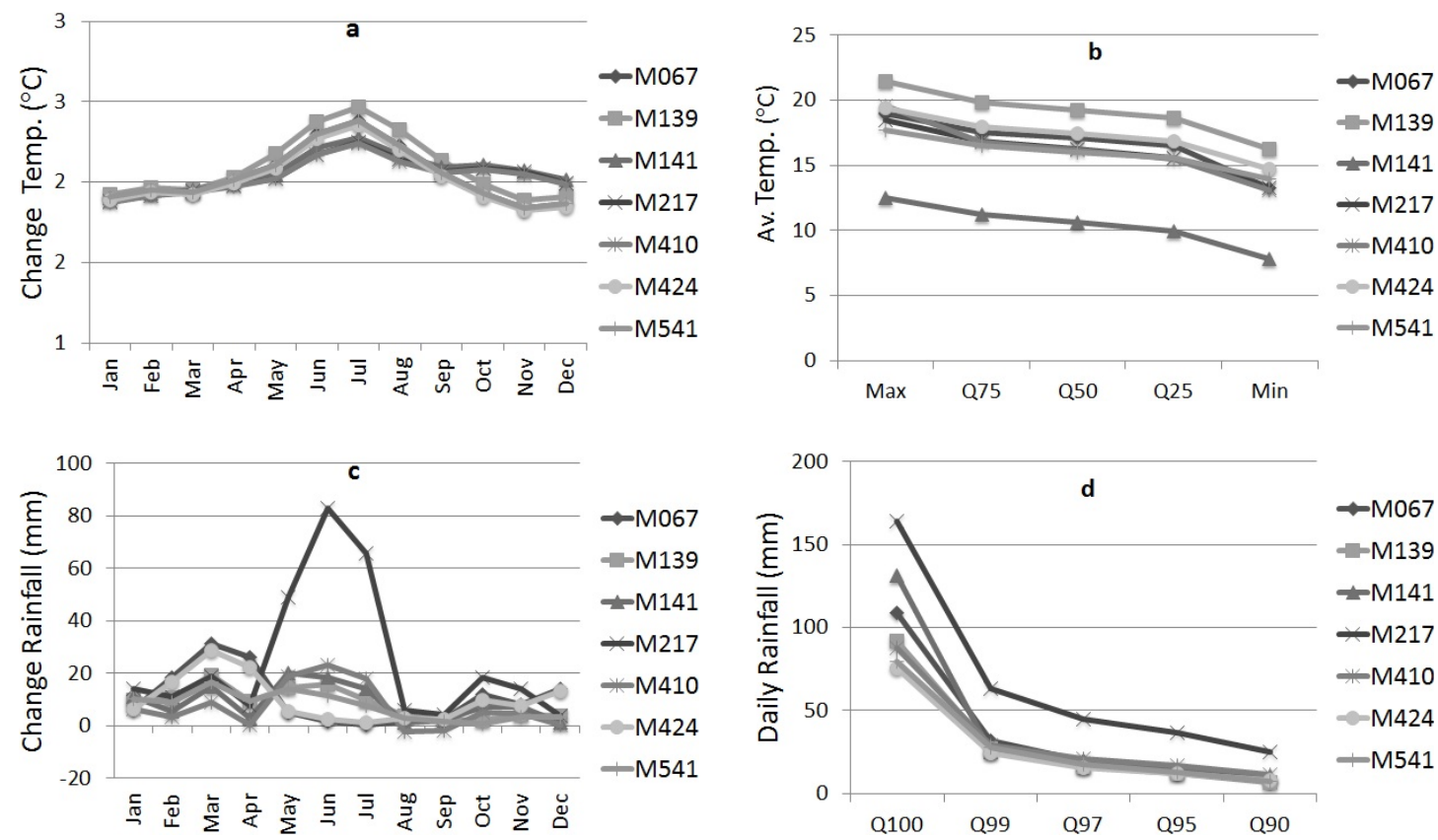

Fig. 7. Temperature and rainfall properties obtained from the average of ensemble downscaled series (2045-2065). (a) Monthly average temperature distribution, (b) monthly temperature for different quantiles, (c) monthly rainfall depth distribution, (d) daily rainfall depth for different quantiles.

Table 4. Impact indicators for temperature and rainfall downscaled output series for 2045-2065, scenario A2.

\begin{tabular}{|c|c|c|c|c|c|c|c|c|c|c|}
\hline \multirow{2}{*}{$\begin{array}{l}\text { Temperature } \\
\text { Site }\end{array}$} & \multirow{2}{*}{$\begin{array}{l}\text { Annual } \\
\text { mean } \\
{\left[{ }^{\circ} \mathrm{C}\right]}\end{array}$} & \multirow{2}{*}{$\begin{array}{l}\text { Abs. changes } \\
\text { in annual } \\
\text { mean } \\
{\left[{ }^{\circ} \mathrm{C}\right]}\end{array}$} & \multicolumn{8}{|c|}{ Abs. changes quantiles $\left[{ }^{\circ} \mathrm{C}\right]$} \\
\hline & & & Max & & $Q_{3}$ & $Q_{2}$ & & $Q_{1}$ & & Min \\
\hline M067 & 17.0 & 2.0 & 2.1 & & 2.1 & 2.1 & & 2.1 & & 2.2 \\
\hline M139 & 19.2 & 2.1 & 2.0 & & 2.1 & 2.0 & & 2.1 & & 2.0 \\
\hline M141 & 10.5 & 2.1 & 2.1 & & 2.0 & 2.0 & & 2.0 & & 2.1 \\
\hline M217 & 16.2 & 2.0 & 1.9 & & 2.0 & 2.0 & & 2.1 & & 2.0 \\
\hline M410 & 16.1 & 2.0 & 1.9 & & 2.0 & 1.9 & & 2.2 & & 2.0 \\
\hline M424 & 17.4 & 2.0 & 2.0 & & 2.0 & 2.0 & & 2.0 & & 1.8 \\
\hline M541 & 16.0 & 2.0 & 2.1 & & 2.1 & 2.0 & & 2.0 & & 1.9 \\
\hline Rainfall & Annual & Abs. (Relative) & \multicolumn{3}{|c|}{ Frequency } & \multicolumn{5}{|c|}{ Abs. change in quantiles [mm] } \\
\hline Site & $\begin{array}{l}\text { mean } \\
{[\mathrm{mm}]}\end{array}$ & $\begin{array}{l}\text { changes in } \\
\text { annual mean } \\
{[\mathrm{mm}]([\%])}\end{array}$ & $\begin{array}{l}N_{\text {wet }} \\
\text { days }\end{array}$ & $\begin{array}{l}N_{\text {dry }} \\
\text { days }\end{array}$ & $\begin{array}{c}\text { Ratio } \\
N_{\text {wet }} / N_{\text {total }}\end{array}$ & $Q_{100}$ & $Q_{99}$ & $Q_{97}$ & $Q_{95}$ & $Q_{90}$ \\
\hline M067 & 967 & $127(15.1)$ & 2518 & 4787 & 0.3 & 48.1 & 5.4 & 2.4 & 2.0 & 0.7 \\
\hline M139 & 841 & $105(14.3)$ & 2448 & 4857 & 0.3 & 25.9 & 2.7 & 1.6 & 1.2 & 0.7 \\
\hline M141 & 1497 & $105(7.5)$ & 5747 & 1558 & 0.8 & 35.9 & 3.1 & 2.0 & 1.4 & 0.7 \\
\hline M217 & 3292 & $295(9.8)$ & 5444 & 1861 & 0.7 & 62.2 & 9.5 & 5.9 & 4.7 & 2.8 \\
\hline M410 & 1381 & $84(6.5)$ & 3779 & 3526 & 0.5 & 27.7 & 3.4 & 2.1 & 1.7 & 0.9 \\
\hline M424 & 903 & $120(15.3)$ & 2688 & 4617 & 0.4 & 30.9 & 4.6 & 2.3 & 1.8 & 0.7 \\
\hline M541 & 902 & $79(9.8)$ & 2664 & 4641 & 0.4 & 25.2 & 2.9 & 1.6 & 1.1 & 0.7 \\
\hline
\end{tabular}


Table 5. Impact indicators for temperature and rainfall downscaled output series for 2045-2065, scenarios A1B and B1.

\begin{tabular}{|c|c|c|c|c|c|c|c|c|}
\hline \multicolumn{2}{|c|}{ Temperature } & \multirow{2}{*}{$\begin{array}{l}\text { Annual } \\
\text { mean } \\
{\left[{ }^{\circ} \mathrm{C}\right]}\end{array}$} & \multirow{2}{*}{$\begin{array}{l}\text { Abs. changes } \\
\text { in annual } \\
\text { mean } \\
{\left[{ }^{\circ} \mathrm{C}\right]}\end{array}$} & \multicolumn{5}{|c|}{ Abs. changes quantiles $\left[{ }^{\circ} \mathrm{C}\right]$} \\
\hline Sc. & Site & & & Max & $Q_{3}$ & $Q_{2}$ & $Q_{1}$ & Min \\
\hline $\mathrm{A} 1 \mathrm{~B}$ & M067 & 16.9 & 2.0 & 2.2 & 2.1 & 2.0 & 2.0 & 2.1 \\
\hline A1B & M139 & 19.1 & 2.0 & 2.0 & 2.1 & 2.0 & 2.0 & 1.9 \\
\hline A1B & M141 & 10.5 & 2.0 & 2.1 & 2.0 & 2.0 & 1.9 & 2.1 \\
\hline $\mathrm{A} 1 \mathrm{~B}$ & M217 & 16.1 & 2.0 & 2.0 & 2.0 & 2.0 & 2.0 & 1.9 \\
\hline A1B & M410 & 16.1 & 2.0 & 2.0 & 2.0 & 1.9 & 2.1 & 1.9 \\
\hline A1B & M424 & 17.4 & 2.0 & 2.0 & 2.1 & 2.0 & 2.0 & 1.9 \\
\hline A1B & M541 & 15.9 & 2.0 & 2.2 & 2.1 & 2.0 & 2.0 & 1.9 \\
\hline B1 & M067 & 15.6 & 0.7 & 1.8 & 0.7 & 0.6 & 0.6 & 0.8 \\
\hline B1 & M139 & 17.5 & 0.4 & 0.4 & 0.5 & 0.4 & 0.4 & 0.3 \\
\hline B1 & M141 & 8.9 & 0.5 & 0.6 & 0.4 & 0.4 & 0.4 & 0.6 \\
\hline B1 & M217 & 14.6 & 0.5 & 0.4 & 0.4 & 0.5 & 0.5 & 0.6 \\
\hline B1 & M410 & 14.5 & 0.5 & 0.4 & 0.4 & 0.4 & 0.6 & 0.4 \\
\hline B1 & M424 & 15.8 & 0.5 & 0.5 & 0.5 & 0.4 & 0.5 & 0.4 \\
\hline B1 & M541 & 14.3 & 0.4 & 0.5 & 0.4 & 0.4 & 0.4 & 0.4 \\
\hline \multirow{2}{*}{\multicolumn{2}{|c|}{ Rainfall }} & Annual & Abs. (Relative) & \multicolumn{5}{|c|}{ Abs. change in quantiles [mm] } \\
\hline & & mean & $\begin{array}{l}\text { changes in } \\
\text { annual mean }\end{array}$ & & & & & \\
\hline Sc. & Site & {$[\mathrm{mm}]$} & {$[\mathrm{mm}]([\%])$} & $Q_{100}$ & $Q_{99}$ & $Q_{97}$ & $Q_{95}$ & $Q_{90}$ \\
\hline A1B & M067 & 923 & $82(9.8)$ & 30.3 & 2.5 & 1.1 & 1.1 & 0.6 \\
\hline A1B & M139 & 817 & $81(11.0)$ & 19.9 & 2.4 & 1.2 & 0.9 & 0.6 \\
\hline A1B & M141 & 1498 & $106(7.6)$ & 22.0 & 2.9 & 2.1 & 1.4 & 0.8 \\
\hline A1B & M217 & 3249 & $252(8.4)$ & 50.2 & 10.9 & 5.4 & 3.8 & 2.3 \\
\hline A1B & M410 & 1415 & $119(9.2)$ & 19.2 & 4.0 & 2.2 & 1.8 & 1.0 \\
\hline A1B & M424 & 874 & 91 (11.6) & 27.4 & 3.8 & 1.9 & 1.5 & 0.6 \\
\hline A1B & M541 & 891 & 78 (9.6) & 18.4 & 2.2 & 1.5 & 1.0 & 0.6 \\
\hline B1 & M067 & 921 & $81(9.6)$ & 27.9 & 2.6 & 1.3 & 1.5 & 0.7 \\
\hline B1 & M139 & 796 & $61(7.6)$ & 18.6 & 1.4 & 0.8 & 0.6 & 0.5 \\
\hline B1 & M141 & 1463 & $71(4.9)$ & 17.5 & 1.7 & 1.2 & 0.8 & 0.4 \\
\hline B1 & M217 & 3245 & $248(7.6)$ & 53.5 & 11.0 & 6.6 & 4.4 & 2.3 \\
\hline B1 & M410 & 1370 & $73(5.4)$ & 15.0 & 1.9 & 1.2 & 1.3 & 0.6 \\
\hline B1 & M424 & 847 & $64(7.5)$ & 22.2 & 1.9 & 1.3 & 1.3 & 0.6 \\
\hline B1 & M541 & 870 & 57 (6.6) & 19.5 & 1.4 & 1.0 & 0.6 & 0.5 \\
\hline
\end{tabular}

in the observed series, it is also transferred to the statistically downscaled series, as opposed to the non-downscaled series. However, the change in temperature quantiles is again approximately the same $\left(+2.0^{\circ} \mathrm{C}\right)$ for all sites. This is due to the fact that the changes in temperature are mainly controlled by the changes in the large-scale circulation (GCM outputs), as discussed before in Sect. 3.2.

When the downscaled series of temperature are compared among the different scenarios, no significant differences are found between scenario A1B and A2 and annual average temperature changes remain approximately constant $\left(+2.0^{\circ} \mathrm{C}\right)$ for the different sites. However, annual average temperature changes projected for scenario B1 indicate a low increase compared to the other scenarios $\left(+0.5^{\circ} \mathrm{C}\right)$. This will have an effect on the runoff changes, as discussed in the next section. Changes in the temperature quantile distributions are similar $\left(\mathrm{ca} .+2.0^{\circ} \mathrm{C}\right.$ for scenarios $\mathrm{A} 1 \mathrm{~B}$ and $\mathrm{A} 2$, and ca. $+0.5^{\circ} \mathrm{C}$ for scenario B1). All scenarios project higher changes for colder months and lower changes for warmer months.

For rainfall, the effect of the statistical downscaling is more evident than for temperature. The projected annual rainfall depths differ from site to site. In addition the changes are less homogenous as was the case for the direct results of the climate models. For instance, sites M541 and M217 project positive changes in annual rainfall depths of +79 and 
Table 6. Absolute (relative) change in annual runoff quantiles for the To Mo and Ma Sa catchments, all scenarios.

\begin{tabular}{llcrlll}
\hline \multicolumn{7}{c}{ Change in runoff depth $\left[\mathrm{mm} \mathrm{d}^{-1}\right]([\%])$} \\
\hline Scenario & Site & \multicolumn{1}{c}{ Min } & $Q_{1}$ & Average & $Q_{3}$ & Max \\
\hline A1B & To Mo & $-0.05(-38)$ & $-0.01(-0.4)$ & $0.12(7.7)$ & $0.19(9.4)$ & $3.19(45)$ \\
A2 & To Mo & $-0.07(-50)$ & $-0.02(-2.2)$ & $0.17(10.5)$ & $0.27(13.7)$ & $4.84(68)$ \\
B1 & To Mo & $-0.05(-34)$ & $0.01(1.2)$ & $0.13(8.6)$ & $0.21(10.6)$ & $2.89(41)$ \\
A1B & Ma Sa & $-0.12(-39)$ & $0.07(3.7)$ & $0.34(11.9)$ & $0.50(14.3)$ & $4.23(34)$ \\
A2 & Ma Sa & $-0.16(-51)$ & $0.03(1.3)$ & $0.34(12.0)$ & $0.53(15.2)$ & $5.33(43)$ \\
B1 & Ma Sa & $-0.13(-41)$ & $0.03(1.4)$ & $0.21(7.4)$ & $0.31(8.8)$ & $2.91(24)$ \\
\hline
\end{tabular}

$+295 \mathrm{~mm}$, respectively. In contrast to the climate model outputs, the downscaled rainfall series show heterogeneous changes in monthly rainfall depths, following the patterns found at observed series (Sect. 3.1). The spatio-temporal patterns of the rainfall changes follow the bimodal or unimodal distributions, with higher changes are projected for wetter months and lower changes (decreasing depths in some cases) for drier months. The frequencies of wet/dry days differ from those projected by the climate model outputs. The ratio of the number of wet days over the total number of days is 0.35 at sites M067, M139 (BM1), 0.5 at site M410 (UM1), 0.75 at site M217 (UM2) and 0.8 at site M141 (BM2). This is similar to the frequencies obtained from the observed series. Also the quantile distributions derived from the downscaled series are closer to the quantile distributions derived from the observed series. This is the result of the intrinsic climate bias involved in the selected QPA statistical downscaling method. When rainfall changes are analyzed, extreme quantile changes are also different than those projected by the climate model outputs. Higher changes are projected at higher intensities. The $100 \%$ quantiles project the highest changes. These changes vary in magnitude depending on the location (i.e. $+62 \mathrm{~mm}$ for site M217 and $+25 \mathrm{~mm}$ for site M541). The $99 \%$ quantiles, in contrast to those obtained from the direct output of GCM/RCMs, still show significant changes.

The rainfall increase depends on the scenario and the site. The highest absolute increase is projected for site M217 (ca. $+250 \mathrm{~mm}$ ) for all scenarios, whereas site M541 shows the lowest increase $(<+80 \mathrm{~mm})$ for all scenarios. The temporal pattern of changes in the different scenarios is similar. There is a higher rainfall increase for wet periods and a lower increase for the dry periods. However, when relative changes in rainfall are analyzed, higher changes occur in sites located in the middle part of the basin, that is, sites M067, M139 and M424 with relative changes of ca. 10, 15 and $8 \%$ for scenarios A1B, A2 and B1, respectively (see Fig. 8). When the frequency of wet/dry days is compared to those obtained from the observed series, a reduction in the number of wet days is found for all sites and for all scenarios. The projected increase in annual and monthly rainfall depths thus is due to increasing rainfall intensities for the remaining wet days. Scenario A2 is the scenario that shows the higher reduction in the number of wet events and the higher increase in annual and monthly rainfall depths versus the other scenarios.

The changes in quantiles indicate that the more extreme events are affected by higher rainfall increases. Sites M217, M424 and M067 show the highest increases in the rainfall extremes for all scenarios. Also site M141 presents high rainfall intensity changes but only for scenario A2. This scenario A2 shows for all sites the highest changes in rainfall extremes in comparison with the other scenarios.

\subsection{Impacts on runoff}

Changes in runoff discharges are analyzed based on the same types of impact indicators than for rainfall and temperature. First, the conversion of discharges in runoff depth was made. When annual averaged runoff is analyzed, Ma Sa shows a higher increase (ca. $+0.30 \mathrm{~mm} \mathrm{day}^{-1}$ ) than To Mo $\left(\right.$ ca. $\left.+0.14 \mathrm{~mm}_{\text {day }}{ }^{-1}\right)$. These absolute changes correspond to relative changes of ca. $8 \%$ for To Mo and ca. $10 \%$ for Ma Sa (see Fig. 9). When runoff is analyzed at different quantiles, high daily runoff extremes indicates that for the To Mo catchment increases are about $+3.6 \mathrm{~mm} \mathrm{day}^{-1}$ and for Ma $\mathrm{Sa}$ about $+4.2 \mathrm{~mm}$ day $^{-1}$. Low quantile daily runoff is about -0.06 and $-0.15 \mathrm{~mm} \mathrm{day}^{-1}$ for the To Mo and Ma Sa respectively. These suggest that higher changes are projected for the Ma Sa catchment. However, relative changes in high quantile indicate higher changes for the To Mo catchment, that is, $68 \%$ for To Mo and $43 \%$ for Ma Sa for scenario A2 (see Table 6). This difference might be due to the lower runoff in the To Mo catchment compared with to the $\mathrm{Ma} \mathrm{Sa}$ catchment. When interpreting these impact results on runoff, it is worth mentioning that the runoff results have higher uncertainty for the To Mo catchment.

The changes in runoff are obviously related to the changes in rainfall and temperature. The increase in high runoff extremes is mainly controlled by the increase in rainfall extremes. Consequently, as for rainfall, higher changes in runoff are observed for extremes (higher quantiles). In contrast, the negative changes in low runoff events are due to the increase in temperature and to the low increase in rainfall for some scenarios. Higher changes in temperature are presumed to produce higher evapotranspiration causing a decrease in 

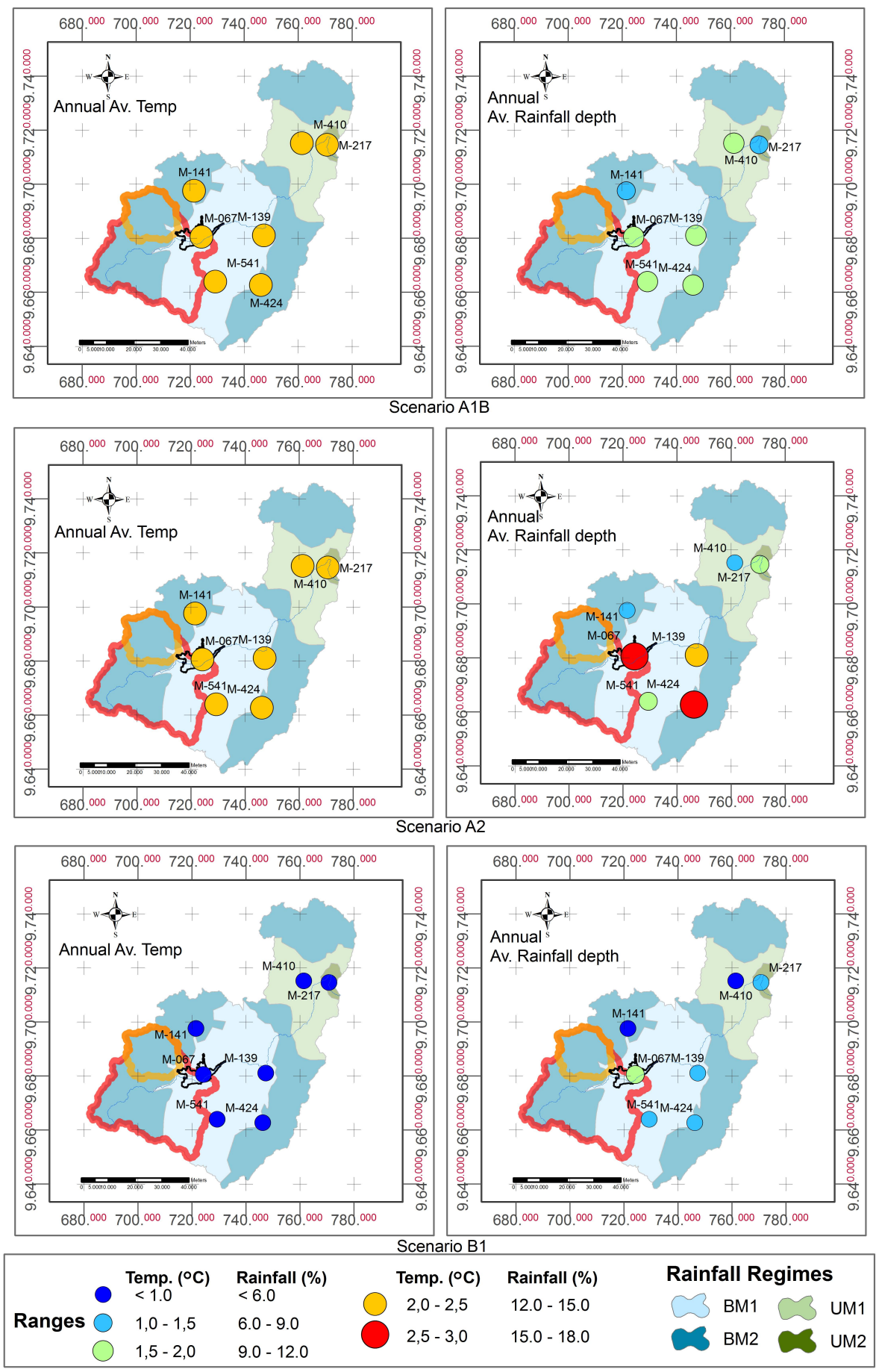

Fig. 8. Map of average change for annual temperature and annual rainfall depth (2045-2065, all scenarios).

low runoff flows. In addition, the reduction in the number of wet days contributes to the decrease in runoff. This is shown for the low runoff flows in the To Mo catchment for scenario $\mathrm{A} 1 \mathrm{~B}$, in which daily runoff below quartile $Q_{3}$ shows lesser increase despite the fact that the rainfall increase is lower for scenario B1. However, in catchment Ma Sa, the effect of low changes in temperature is not reflected in the runoff. This might be explained by the more uniform rainfall distribution in that catchment due to which changes in runoff are also more uniformly distributed. 

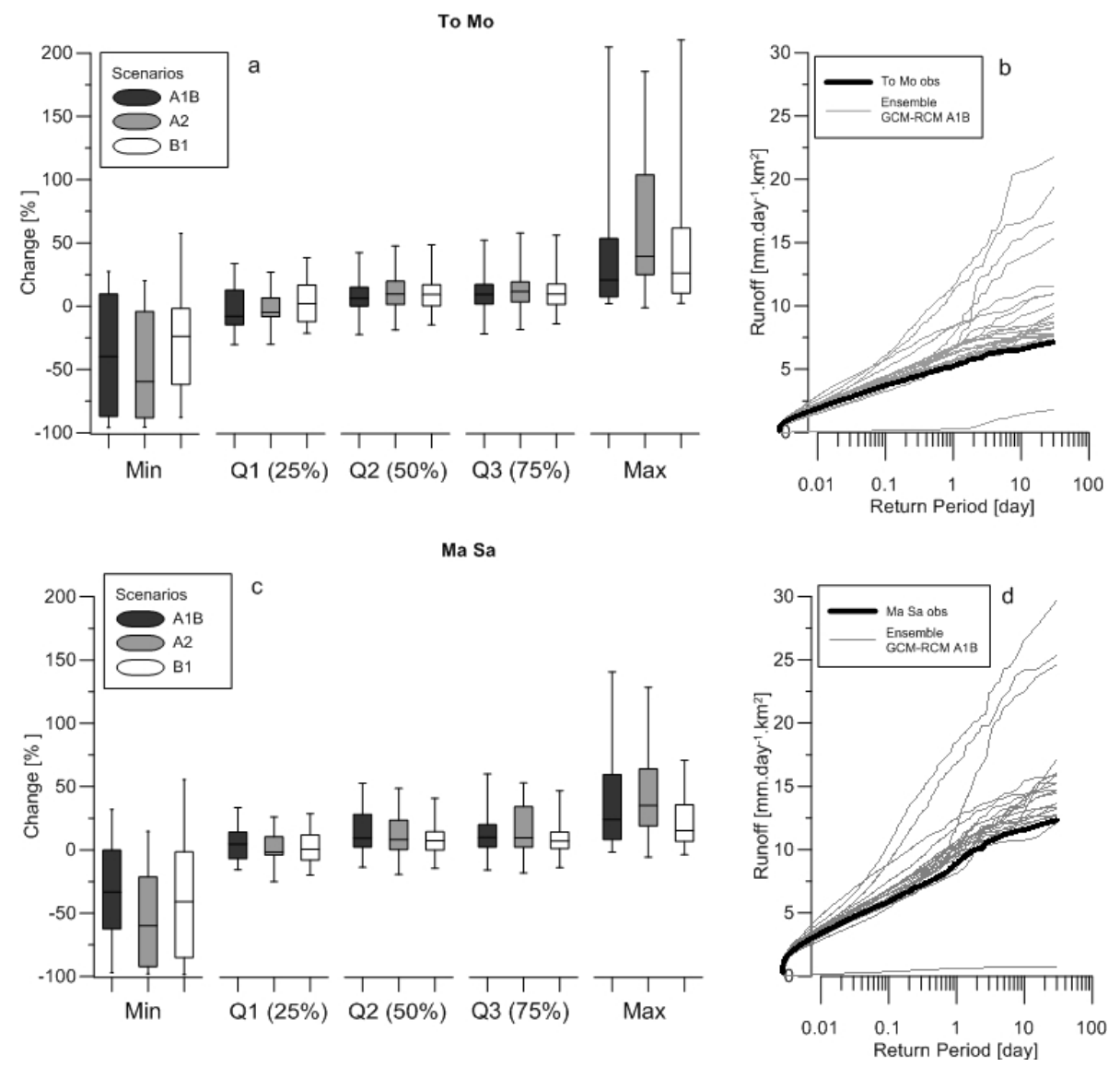

Fig. 9. Projected changes in daily runoff for To Mo and Ma Sa catchments (2045-2065). (a) and (c) relative changes in runoff quantiles (all scenarios), (b) and (d) extreme runoff vs. return period (scenario A1B).

\section{Conclusions}

This study brings new knowledge about the impact of climate change in the tropical Andean basin of the Paute River, which is strongly related to the high heterogeneity of the region. This knowledge might be useful to determine the climate change impacts on water resources.

Within the analysis of the GCM-RCM outputs, the RCMbased temperature changes are mainly driven by the largescale circulation models in which the RCM is nested. This is different for the RCM projected rainfall changes, which show that topographical or other local dynamics control the climate projections. However, rainfall patterns are not similar to those identified in the observed series and inconsistent changes are projected. This brings some discussion on the accuracy of RCM outputs and its direct use, although we believe that the inclusion of RCM outputs should be considered for statistical downscaling together with the GCM outputs. RCMs indeed intrinsically involve climate dynamics acting at spatial scales smaller than the coarse GCM resolution.

The comparison between climate model outputs and downscaled series for scenario A2 shows that the local variation in temperature and rainfall are properly identified and transferred to the downscaled series with the advanced QPA downscaling technique. This, however, requires good quality observed data with a temporal resolution that is sufficient to derive the local patterns which might influence the results. In this study, this was the monthly resolution for temperature and the daily resolution for rainfall.

As other statistical downscaling techniques, the present methodology has some limitations. First, the method does account for (and transfer) the local properties that control the spatial variability in the meteorological variables from the observed series, but future changes in these properties are not taken into account. As explained before, we (and several other authors) expect that the properties (such as local topography) are not subject to future changes. This, however, needs further investigation (e.g. based on high resolution $\mathrm{RCMs}$ ). Second, although the method applied for addressing the wet/dry day changes is systematic, it still is a rather crude method based on assumptions regarding the clustering of wet spells, which needs further investigation.

Nevertheless, the proposed downscaling technique is considered to be a potential option to assess local climate impacts. Cloke et al. (2013) also encourage the use of 
statistical downscaling techniques above the direct use of RCMs. However, these techniques must be used together with multiple evidence streams considering grand ensembles of GCM/RCM. In addition, other downscaling techniques can be compared with the proposed technique. In this way, this sensitivity of the downscaled impact results to the assumptions underlying statistical downscaling can be tested. One interesting analysis would be the comparison between statistical downscaling methods that make direct use of the rainfall results of climate models and statistical downscaling techniques that take advantage of observed relationships between rainfall and large-scale circulation.

From the downscaled results it was learned that the changes in annual averaged temperature are homogeneous for almost the entire region with an increase of about $+2.0^{\circ} \mathrm{C}$. Despite the fact that the temperature variability between sites was properly identified and transferred by the downscaling technique, no difference in the changes was found related to the spatial scale. However, this homogeneity may be due to the monthly temporal resolution of the observed data. Therefore, higher resolution (i.e. daily) temperature series need to be explored in future research.

Despite the stable annual temperature average, the temperature changes differ at temporal scale. The warmest period of the year would experience lower changes than the colder ones, and the coldest period of the year would have higher changes. This finding disagrees with the idea that warmer months will become warmer and that colder months will become colder. Another insight gained from the temperature impact assessment is that scenario B1 brings the lowest temperature increase, whereas scenarios A1B and scenario A2 show similar changes in temperature. This differs from other temperature impact results around the world, where scenario $\mathrm{A} 2$ projects the highest temperatures among other scenarios.

For rainfall, the changes are more heterogeneous than the changes projected for temperature. The downscaled results project an annual rainfall depth increase along the basin for all sites and for all scenarios. No site and no scenario indicate decrease in annual rainfall depths. However, the frequency of wet days reduces. This suggests that the annual rainfall depth increase is due an increase in the remaining wet day intensities, as was confirmed by quantile analysis. Higher rainfall increases are indeed projected for more extreme rainfall intensity events.

Absolute changes in runoff are higher for the Ma Sa catchment than for the To Mo catchment, both higher increases in high runoff flows and stronger decreases in the low runoff flows. The increase in high runoff extremes can be linked to the fact that the Ma Sa catchment is more wet than the To Mo catchment. The changes in extreme rainfall intensities are indeed also higher in the wetter regions (i.e. sites M217, M141). Therefore, changes in high runoff extremes are mainly related to the changes of rainfall extremes for both catchments, whereas the decrease in low runoff flows are linked to the increase in temperature together with the reduction in the number of wet days. However, this conclusion should be taken with care, as climate change might influence other hydrological catchment characteristics that were not taken into account in this study. This is the case for parameters involved in the estimation of evapotranspiration. In this research, future variables of solar radiation, humidity and wind speed were kept constant, overestimating the $\mathrm{ET}_{0}$ values. Other hydrological parameters not taken into account are the ones related to the soil properties of the páramo tropical alpine region, which involves a high water retention capacity that is highly dependent on cold temperatures (Buytaert et al., 2011).

The climate change found in this study for temperature, rainfall and runoff might bring consequences to the hydrological processes and related water management needs; hence, this will need further investigation as well.

Acknowledgements. The research was feasible thanks to a grant of the Selective Bilateral Agreement of the KU Leuven, Belgium, and its cooperation with the Universidad de Cuenca, Ecuador. The research was made within the frame of the VLIR-IUC project Integrated Water Quality Management. Special thanks go to the staff of the Hydraulics Division of KU Leuven and to PROMAS - U. Cuenca for the support in research activities and data access, and to Rolando Celleri for his support in the application of the VHM model.

Edited by: F. Pappenberger

\section{References}

Andréasson, J., Bergström, S., Carlsson, B., Graham, L. P., and Lindström, G.: Hydrological Change - Climate Change Impact Simulations for Sweden, Ambio, 33, 228-234, 2004.

Beldring, S., Engen-Skaugen, T., Førland, E. J., and Roald, L. A.: Climate change impacts on hydrological processes in Norway based on two methods for transferring regional climate model results to meteorological station sites, Tellus A, 60, 439-450, 2008.

Buytaert, W., Vuille, M., Dewulf, A., Urrutia, R., Karmalkar, A., and Célleri, R.: Uncertainties in climate change projections and regional downscaling in the tropical Andes: implications for water resources management, Hydrol. Earth Syst. Sci., 14, 12471258, doi:10.5194/hess-14-1247-2010, 2010.

Buytaert, W., Cuesta-Camacho, F., and Tobón, C.: Potential impacts of climate change on the environmental services of humid tropical alpine regions, Global Ecol. Biogeogr., 20, 19-33, 2011.

Célleri, R., Willems, P., Buytaert, W., and Feyen, J.: Space-time rainfall variability in the Paute basin, Ecuadorian Andes, Hydrol. Process., 21, 3316-3327, 2007.

Célleri, R., Willems, P., and Feyen, J.: Evaluation of a data-based hydrological model for simulating the runoff of medium sized Andean basins, Maskana Vol. 1, U. Cuenca, Cuenca, Ecuador, 61-77, 2010. 
Cloke, H. L., Wetterhall, F., He, Y., Freer, J. E., and Pappenberger, F.: Modelling climate impact on floods with ensemble climate projections. Q. J. Roy. Meteorol. Soc., 139, 282-297, doi:10.1002/qj.1998, 2013.

Coltorti, M. and Ollier, C.: Geomorphic and tectonic evolution of the Ecuadorian Andes, Geomorphology, 32, 1-19, 2000.

Dirmeyer, P. A., Cash, B. A., Kinter, J. L., Stan, C., Jung, T., Marx, L., Towers, P., Wedi, N., Adams, J. M., Altshuler, E. L., Huang, B., Jin, E. K., and Manganello, J.: Evidence for Enhanced LandAtmosphere Feedback in a Warming Climate, J. Hydrometeorol., 13, 981-995, 2012.

Fowler, H. J., Blenkinsop, S., and Tebaldi, C.: Linking climate change modelling to impacts studies: recent advances in downscaling techniques for hydrological modelling, Int. J. Climatol., 27, 1547-1578, 2007.

Garreaud, R. D.: The Andes climate and weather, Adv. Geosci., 22, 3-11, doi:10.5194/adgeo-22-3-2009, 2009.

Giorgi, F., Christensen, J., Hulme, M., von Storch, H., Whetton, P., Jones, R., Mearns, L., Fu, C., Arritt, R., Bates, B., Benestad, R., Boer, G., Buishand, A., Castro, M., Chen, D., Cramer, W., Crane, R., Crossly, J., Dehn, M., Dethloff, K., Dippner, J., Emori, S., Francisco, R., Fyfe, J., Gerstengarbe, F., Gutowski, W., Gyalistras, D., Hanssen-Bauer, I., Hantel, M., Hassell, D., Heimann, D., Jack, C., Jacobeit, J., Kato, H., Katz, R., Kauker, F., Knutson, T., Lal, M., Landsea, C., Laprise, R., Leung, L., Lynch, A., May, W., McGregor, J., Miller, N., Murphy, J., Ribalaygua, J., Rinke, A., Rummukainen, M., Semazzi, F., Walsh, K., Werner, P., Widmann, M., Wilby, R., Wild, M., and Xue, Y.: Regional Climate Information- Evaluation and Projections, Climate Change 2001: The Scientific Basis, in: Contribution of Working Group to the Third Assessment Report of the Intergouvernmental Panel on Climate Change, edited by: Houghton, J. T., Ding, Y., Griggs, D. J., Noguer, M., van der Linden, P. J., Dai, X., Maskell, K., and Johnson, C. A., http://epic.awi.de/4973/, Cambridge University Press, Cambridge, UK and New York, USA, 2001.

Harrold, T. I. and Jones, R.: Downscaling of GCM rainfall: A refinement of the perturbation method, in: EGS-AGU-EUG Joint Assembly, Presented at the EGS-AGU-EUG Joint Assembly, 611 April, Nice, France, p. 1338, 2003.

Hewitson, B. and Crane, R.: Climate downscaling: techniques and application, Clim. Res., 07, 85-95, 1996.

Hirabayashi, Y., Kanae, S., Emori, S., Oki, T., and Kimoto, M.: Global projections of changing risks of floods and droughts in a changing climate, Hydrolog. Sci. J., 53, 754-772, 2008.

Liu, T., Willems, P., Pan, X. L., Bao, An. M., Chen, X., Veroustraete, F., and Dong, Q. H.: Climate change impact on water resource extremes in a headwater region of the Tarim basin in China, Hydrol. Earth Syst. Sci., 15, 3511-3527, doi:10.5194/hess-15-35112011, 2011.

Maraun, D., Wetterhall, F., Ireson, A. M., Chandler, R. E., Kendon, E. J., Widmann, M., Brienen, S., Rust, H. W., Sauter, T., Themeß1, M., Venema, V. K. C., Chun, K. P., Goodess, C. M., Jones, R. G., Onof, C., Vrac, M., and Thiele-Eich, I.: Precipitation downscaling under climate change: Recent developments to bridge the gap between dynamical models and the end user, Rev. Geophys., 48, RG3003, doi:10.1029/2009RG000314, 2010.
Middelkoop, H., Daamen, K., Gellens, D., Grabs, W., Kwadijk, J C. J., Lang, H., Parmet, B. W. A. H., Schädler, B., Schulla, J., and Wilke, K.: Impact of Climate Change on Hydrological Regimes and Water Resources Management in the Rhine Basin, Climatic Change, 49, 105-128, 2001.

Monteith, J.: Evaporation and environment, Presented at the Symp. Soc. Exp. Biol, Rothamsted Experimental Station, Harpenden, UK, p. 4, 1965.

Mora, D. E. and Willems, P.: Decadal oscillations in rainfall and air temperature in the Paute River Basin-Southern Andes of Ecuador, Theor. Appl. Climatol., 108, 267-282, 2012.

Mora, D. E., Liu, T., Cisneros, F., Wyseure, G., and Willems, P.: Statistical Analysis on the Performance of Global and Regional Climate Models for the Paute River Basin in the South-Ecuadorian Andes, Proceedings of 10th International Conference on Hydroinformatics, Hamburg, Germany, 2012.

Nakicenovic, N., Alcamo, J., Davis, G., de Vries, B., Fenhann, J., Gaffin, S., Gregory, K., Grubler, A., Jung, T. Y., Kram, T., La Rovere, E. L., Michaelis, L., Mori, S., Morita, T., Pepper, W., Pitcher, H. M., Price, L., Riahi, K., Roehrl, A., Rogner, H.-H., Sankovski, A., Schlesinger, M., Shukla, P., Smith, S. J., Swart, R., van Rooijen, S., Victor, N., and Dadi, Z.: Special Report on Emissions Scenarios: A Special Report of Working Group III of the Intergovernmental Panel on Climate Change (No. PNNLSA-39650), Pacific Northwest National Laboratory, Richland, WA, USA, Environmental Molecular Sciences Laboratory, USA, 2000.

Nguyen, V. T. V., Desramaut, N., and Nguyen, T. D.: Estimation of urban design storms in consideration of GCM-based climate change scenarios, Proceedings International Conference on "Water and Urban Development Paradigms: Towards an Integration of Engineering, Design and Management Approaches", 1517 September, Leuven, Belgium, 347-356, 2008

Nguyen, V.-T.-V., Nguyen, T.-D., and Cung, A.: A statistical approach to downscaling of sub-daily extreme rainfall processes for climate-related impact studies in urban areas, Presented at the Sustainable and Safe Water Supplies, International Water Association, International Symposium, Hong Kong, China, 183-192, 2007.

Nijssen, B., O’Donnell, G., Hamlet, A., and Lettenmaier, D.: Hydrologic Sensitivity of Global Rivers to Climate Change, Climatic Change, 50, 143-175, 2001.

Ntegeka, V. and Willems, P.: Trends and multidecadal oscillations in rainfall extremes, based on a more than 100-year time series of 10 min rainfall intensities at Uccle, Belgium, Water Resour. Res., 44, W07402, doi:10.1029/2007WR006471, 2008.

Olsson, J., Willén, U., and Kawamura, A.: Downscaling extreme short-term regional climate model precipitation for urban hydrological applications, Hydrol. Res., 43, 341-351, 2012.

Ontaneda, G., Garcia, G., and Arteaga, A.: Evidencias del cambio climdtico en Ecuador, Proyecto ECU/99/G31 Cambio Climatico, Fase 2, Comite Nacional sobre el Clima GEF-PNUD, Ministerio del Ambiente, Quito, Ecuador, 2002.

Parry, M. L., Canziani, O. F., Palutikof, J. P., van der Linden, P. J., and Hanson, C. E.: Climate Change 2007: Impacts, Adaptation and Vulnerability: Working Group II Contribution to the Fourth Assessment Report of the Intergovernmental Panel on Climate Change, Vol. 4, Cambridge University Press, UK, 976986, 2007. 
Penman, H. L.: Natural Evaporation from Open Water, Bare Soil and Grass, P. Roy. Soc. Lond., 193, 120-145, 1948.

Prudhomme, C., Reynard, N., and Crooks, S.: Downscaling of global climate models for flood frequency analysis: Where are we now?, Hydrol. Process., 16, 1137-1150, 2002.

Solomon, S., Qin, D., Manning, M., Chen, Z., Marquis, M., Averyt, K., Tignor, M., and Miller, H.: The physical science basis, Contribution of working group I to the Fourth Assessment Report of the Intergovernmental Panel of Climate Change, Cambridge University Press, UK, 235-337, 2007.

Taye, M. T. and Willems, P. : Identifying sources of temporal variability in hydrological extremes of the upper Blue Nile basin, J. Hydrol., 499, 61-70, 2013.

Taye, M. T., Ntegeka, V., Ogiramoi, N. P., and Willems, P.: Assessment of climate change impact on hydrological extremes in two source regions of the Nile River Basin, Hydrol. Earth Syst. Sci., 15, 209-222, doi:10.5194/hess-15-209-2011, 2011.

Urrutia, R. and Vuille, M.: Climate change projections for the tropical Andes using a regional climate model: Temperature and precipitation simulations for the end of the 21 st century, J. Geophys. Res., 114, D02108, doi:10.1029/2008JD011021, 2009.

Van Steenbergen, N. and Willems, P.: Method for testing the accuracy of rainfall-runoff models in predicting peak flow changes due to rainfall changes, in a climate changing context, J. Hydrol., 414-415, 425-434, 2012.
Vuille, M., Bradley, R. S., Werner, M., and Keimig, F.: 20th entury climate change in the tropical Andes: observations and model results, Climatic Change, 59, 75-99, 2003.

Willems, P.: Probabilistic immission modelling of receiving surface waters, PhD Thesis, KU Leuven, Leuven, Belgium, 2000.

Willems P.: Parsimonious rainfall-runoff model construction supported by time series processing and validation of hydrological extremes - Part 1: Step-wise modelstructure identification and calibration approach, J. Hydrol., 510, 578-590, 2014.

Willems, P. and Vrac, M.: Statistical precipitation downscaling for small-scale hydrological impact investigations of climate change, J. Hydrol., 402, 193-205, 2011.

Willems, P., Olsson, J., and Arnbjerg-Nielsen, K.: Impacts of Climate Change on Rainfall Extremes and Urban Drainage Systems, IWA Publishing, London, UK, 239 pp., 2012.

Willems, P., Mora, D. E., Vansteenkiste, Th., Teferi Taye, M., and Van Steenbergen, N.: Parsimonious rainfall-runoff model construction supported by time series processing and validation of hydrological extremes - Part 2: Intercomparison of models and calibration approaches, J. Hydrol., 510, 591-609, 2014.

Wood, A. W., Leung, L. R., Sridhar, V., and Lettenmaier, D. P.: Hydrologic implications of dynamical and statistical approaches to downscaling climate model outputs, Climatic Change, 62, 189216, 2004. 